\title{
Economic viability of UK shale gas and potential impacts on the energy market up to 2030
}

DOI:

10.1016/j.apenergy.2018.02.051

\section{Document Version}

Accepted author manuscript

Link to publication record in Manchester Research Explorer

\section{Citation for published version (APA):}

Cooper, J., Stamford, L., \& Azapagic, A. (2018). Economic viability of UK shale gas and potential impacts on the energy market up to 2030. Applied Energy, 215, 577-590. https://doi.org/10.1016/j.apenergy.2018.02.051

\section{Published in:}

Applied Energy

\section{Citing this paper}

Please note that where the full-text provided on Manchester Research Explorer is the Author Accepted Manuscript or Proof version this may differ from the final Published version. If citing, it is advised that you check and use the publisher's definitive version.

\section{General rights}

Copyright and moral rights for the publications made accessible in the Research Explorer are retained by the authors and/or other copyright owners and it is a condition of accessing publications that users recognise and abide by the legal requirements associated with these rights.

\section{Takedown policy}

If you believe that this document breaches copyright please refer to the University of Manchester's Takedown Procedures [http://man.ac.uk/04Y6Bo] or contact uml.scholarlycommunications@manchester.ac.uk providing relevant details, so we can investigate your claim.

\section{OPEN ACCESS}




\title{
Economic viability of UK shale gas and potential impacts on the energy market up to 2030
}

\author{
Jasmin Cooper, Laurence Stamford and Adisa Azapagic* \\ UK \\ ${ }^{*}$ Corresponding author: Adisa Azapagic \\ Phone: +44 (0)161306 4363 \\ Email: address: adisa.azapagic@manchester.ac.uk
}

Sustainable Industrial Systems, School of Chemical Engineering and Analytical Science, The Mill, Room C16, Sackville Street, The University of Manchester, Manchester M13 9PL,

\begin{abstract}
The UK is in the early stages of developing a shale gas industry and to date six test wells have been drilled but none yet exploited commercially. Some argue that shale gas could reduce energy prices and improve national energy security. However, the costs of bringing commercial-size wells into operation are uncertain and the impact shale gas could have on the UK energy market is currently unknown. Therefore, this paper evaluates the economic viability of developing a UK shale gas industry and the impacts it could have on the UK gas and electricity markets and consumer energy bills up to 2030. The estimated life cycle (levelised) costs of shale gas production range from 0.47-56.74 pence/MJ (0.61-73 US\$ cents/MJ), with an average value of 4.64 pence/MJ. The break-even price at which shale gas can be sold varies between 0.95 and 114.44 pence/MJ, averaging at 9.47 pence/MJ, depending on the volume of gas produced by a shale gas well. The latter is two times higher than imported liquefied natural gas, around 30\% more expensive than UK natural gas and three times greater than the price of US shale gas. Electricity from shale gas is on average $17 \%$ more expensive than from domestic conventional gas but still more competitive than most other electricity options, including coal and renewables. However, the impact of shale gas on the energy market would be limited across the expected range of shale gas penetration into the gas and electricity mixes, suggesting that it would have little effect on energy prices. This is reflected in an almost negligible impact on consumer energy bills. The potential of shale gas to boost the UK economy is also limited, contributing $0.017 \%-0.033 \%$ to the GDP. This is an order of magnitude lower than the contribution of US shale gas to its GDP $(0.2 \%)$, indicating that the economic success of shale gas in the US may not be replicated in the UK. These findings will be of interest to shale gas developers and policy makers not only in the UK but in other countries considering exploitation of shale gas resources.
\end{abstract}

Keywords: shale gas; life cycle costs; electricity; energy costs; natural gas

\section{Introduction}

Shale gas is seen by many countries as a future source of affordable energy and improved energy security. Estimates suggest that it could double current global gas reserves, adding nearly 7299 trillion cubic meters to the total (BP, 2014; Kuuskraa et al., 2013). Given that gas consumption is expected to increase by up to $50 \%$ by 2035 (BP, 2016a; IEA, 2015), it is not surprising that many countries are considering exploiting their shale gas deposits. However, at present, the US is still the only nation to produce it commercially on a large scale. This has led to low gas prices and (almost) self-sufficiency in gas supplies, with the country expected to become a net exporter of gas by 2020 (Conti et al., 2015). The contribution of the shale gas sector to the gross domestic product (GDP) and tax revenue is significant, estimated in 2010 at $\$ 76.9 \mathrm{~m}$ and $\$ 18.6 \mathrm{~m}$, respectively (Fullenbaum et al., 2011). The indirect benefits through boost to industry in general are estimated to be worth billions, including a $\$ 72$ bn in investment by 2020 (ACC, 2011). 
Elsewhere, exploitation of shale gas is lagging behind so that economic impacts in other countries can only be estimated; these estimates are summarised in Table 1 (Cooper et al., 2016). As can be seen, shale gas is much more expensive to produce in other countries than in the US. One of the reasons is the lack of infrastructure and expertise available in the US. Furthermore, all shale gas wells are different, requiring different equipment and, consequently, the investment required is too high for many companies (Bolton and Foxton, 2014; Tian et al., 2014; Yunna and Yisheng, 2014). In addition, test wells have been reported to be less productive than expected (Cooper et al., 2016), making them uneconomic for development.

Table 1: Estimated costs, investment and revenue for exploiting shale gas in the US in comparison with other countries (based on Cooper et al., 2016).

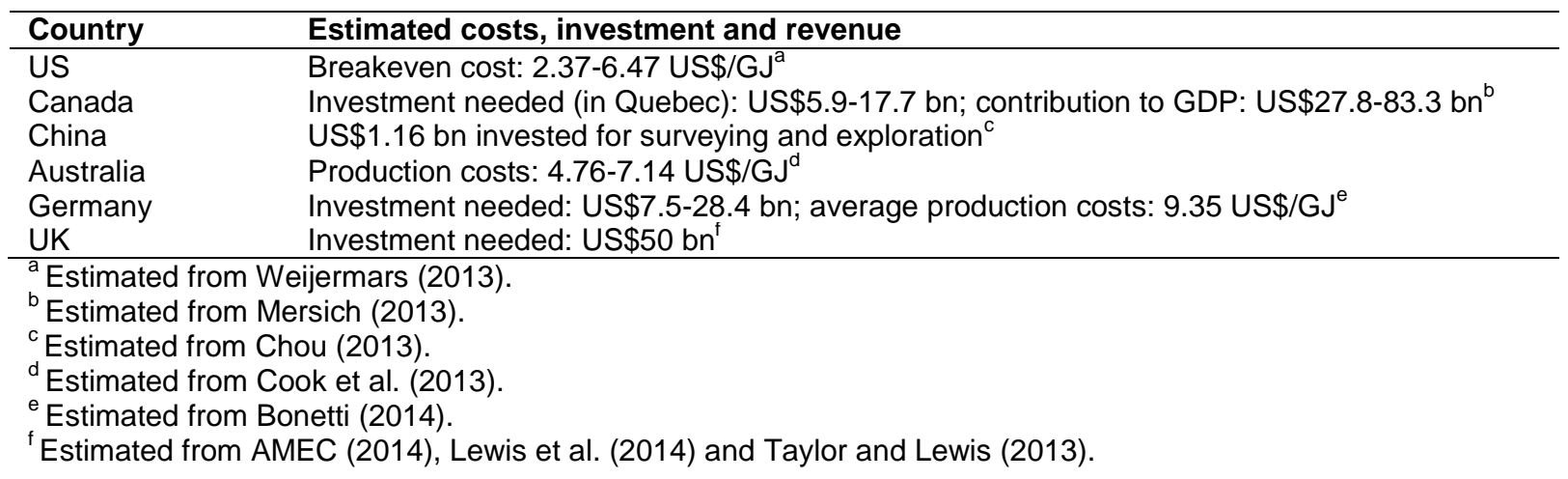

Hoping to emulate the US experience, the UK government is trying to promote shale gas development and has introduced a favourable tax regime to encourage investment (HM Treasury, 2013; HM Treasury, 2014). However, shale gas is a contentious issue in the UK with significant public opposition, largely because of potential environmental impacts and effects on local communities (Cooper et al., 2014; Cooper et al., 2018; Moore et al., 2014; Werner et al., 2015). In an attempt to address some of these concerns, the government has set up a fund to be financed through shale gas tax revenue, aimed at benefiting communities affected by its development (HM Treasury, 2014).

Despite this, the UK's shale gas industry is still in its infancy. Only six wells have been drilled and one hydraulically fractured since drilling began in 2010, all of which are exploration wells (Cuadrilla Resources, 2017b; Gosden and Shiel, 2015; Third Energy, 2016). At the time of writing, the seventh well is being drilled in the north of England, with the aim of commercial exploitation (Gosden, 2017). As a result of the slow progress and small scale of activity, the economic viability of producing shale gas is still uncertain.

Therefore, this paper sets out to estimate, for the first time, the costs of producing shale gas in the UK and the implications this could have for electricity prices and for the UK economy. Taking a life cycle approach, the costs of producing and utilising shale gas to generate electricity are estimated, alongside the effects on gas and electricity prices up to the year 2030. The estimated costs are also compared to alternative sources of electricity, including other fossil-fuel options, renewables and nuclear power. While previous studies considered different cost aspects of shale gas (BNEF, 2013; Weijermars, 2013; Amion, 2014; Lewis et al., 2014; Taylor and Lewis, 2013; Chen et al., 2015; Weijermars et al., 2017), as far as we are aware, this is the first study to integrate different aspects and estimate full life cycle costs (LCC) of shale gas from 'cradle to grave'. It is also the first study to compare its cost to other gas and electricity options as well as to consider the potential future effects of shale gas on the UK economy and household energy bills. A summary of the costs and other related aspects considered in this study in comparison to the literature can be found in Table 2. 
Table 2 Shale gas costs and other related aspects considered in this study and the literature

\begin{tabular}{|c|c|c|}
\hline Economic aspect & $\begin{array}{l}\text { Considered in } \\
\text { this study }\end{array}$ & $\begin{array}{l}\text { Considered in } \\
\text { the literature }\end{array}$ \\
\hline Capital and operating costs of shale gas production & Yes & Yes $^{a}$ \\
\hline Well costs & Yes & Yes $^{\mathrm{b}}$ \\
\hline Wholesale/break-even price of shale gas & Yes & Yes $^{c}$ \\
\hline Community charter costs & Yes & Yes $^{d}$ \\
\hline Life cycle costs of shale gas from cradle to grave & Yes & No \\
\hline Employment per well/pad & Yes & $Y_{e s}^{e}$ \\
\hline Operator and tax revenue & Yes & No \\
\hline Contribution to gross domestic product (GDP) & Yes & No \\
\hline Payback period & Yes & No \\
\hline Indirect economic impacts & Yes & Yes $^{\dagger}$ \\
\hline Life cycle cost of electricity from shale gas & Yes & No \\
\hline Cost of a gas mix which includes shale gas & Yes & No \\
\hline Cost of an electricity mix which includes shale gas & Yes & No \\
\hline $\begin{array}{l}\text { amion (2014); BNEF (2013); Lewis et al. (2014); Ta } \\
\text { b Amion (2014). } \\
{ }^{c} \text { Taylor and Lewis (2013). } \\
{ }^{d} \text { Cronin (2013); UKOOG (2013); Taylor and Lewis (2 } \\
\text { e Taylor and Lewis (2013). } \\
{ }^{f} \text { Lewis et al. (2014). }\end{array}$ & (2014). & \\
\hline
\end{tabular}

\section{Methods}

The method for estimating the LCC of shale gas production and electricity generation is detailed in the next sections, together with the data and key assumptions. Prior to that, the goal and scope of the study are defined below.

\subsection{Goal and scope of the study}

The main goals of this study are:

- to estimate the LCC of UK shale gas, considering its production and utilisation for electricity generation;

- to compare the LCC costs of shale gas to other electricity sources;

- to estimate the potential impact of shale gas on gas and electricity costs and on the UK energy market; and

- to investigate the potential impact of shale gas on the national economy.

The study considers the present situation (without shale gas) and a medium-term future up to the year 2030. The latter explores the effect of different levels of shale gas penetration into the gas and electricity mix. The year 2030 has been selected as it is expected that it will take at least 10 years for the UK to transition from the present exploration drilling to full-scale commercial production (Lewis et al., 2014).

All relevant life cycle stages from 'cradle to grave' are included, as shown in Figure 1. These comprise site exploration, drilling and hydraulic fracturing, shale gas extraction, treatment and distribution, well decommissioning and electricity generation. Power plant construction and decommissioning are also considered. The LCC are estimated per kWh of shale gas produced and per kWh of electricity generated, respectively. 


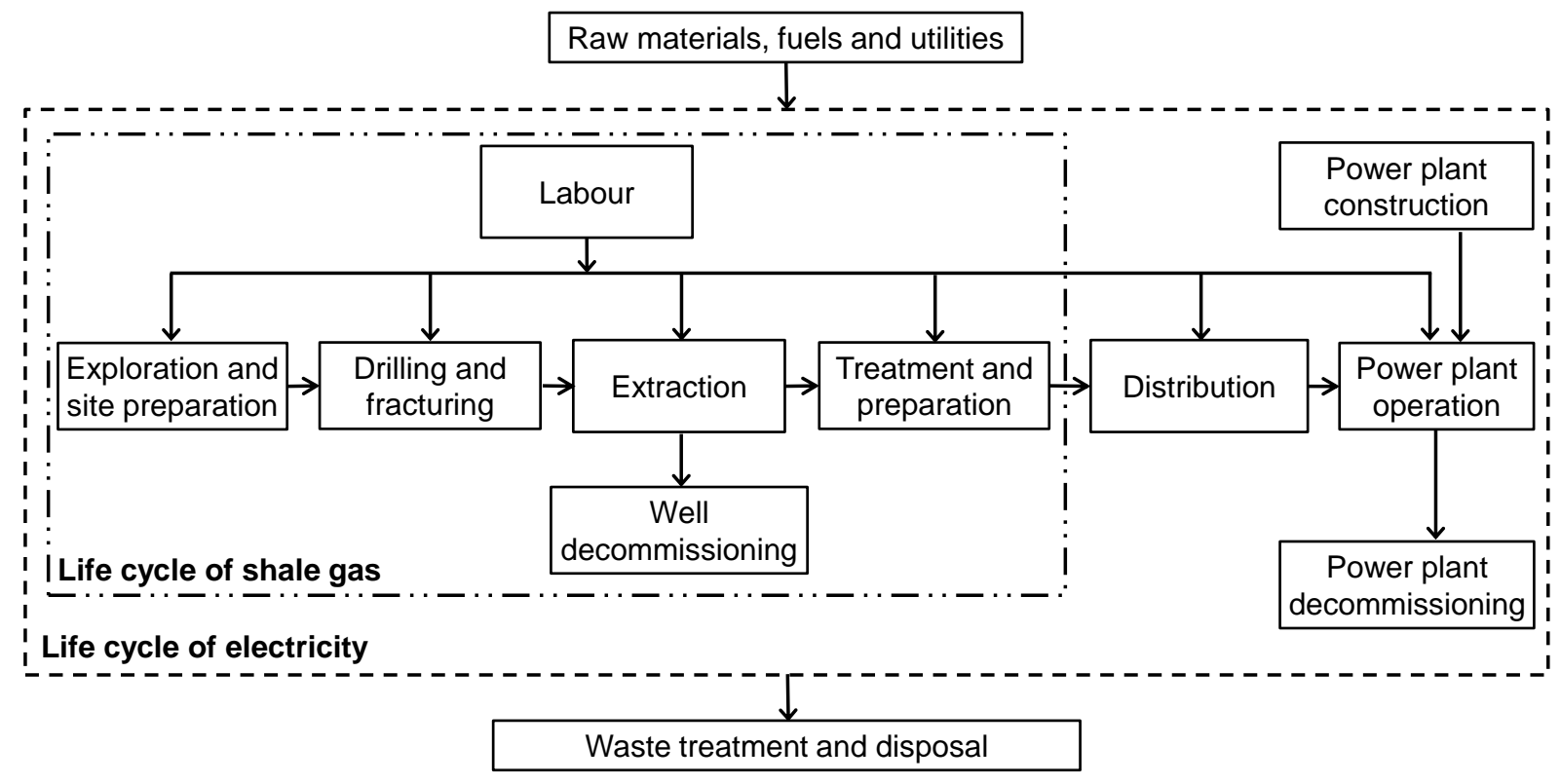

Figure 1: Life cycle stages considered in the estimation of life cycle costs of shale gas production and electricity generation.

\subsection{Calculation of life cycle costs}

This section first outlines the methodology used to estimate the costs of shale gas production, followed by the costs of electricity generation.

\subsubsection{Cost of shale gas production}

The total costs of shale gas production over the lifetime of a well have been estimated as follows:

$L C C_{S G=} \frac{\sum_{n=1}^{N} C_{S G, n}}{E_{S G}} \times 10^{2} \quad$ (pence $\left./ \mathrm{kWh}\right)$

where:

$L C C_{S G} \quad$ life cycle costs of shale gas (pence/kWh)

$C_{S G, n} \quad$ total costs of shale gas production in year $n(£)$

$E_{S G} \quad$ energy content of shale gas produced over the lifetime of the well $(\mathrm{kWh})$

$n \quad$ year $n$ (year)

$N \quad$ lifetime of the shale gas well (years).

The total cost of shale gas production $C_{S G, n}$ in year $n$ is equal to the sum of capital, operating, maintenance and labour costs in that year:

$$
C_{S G, n}=C C_{S G, n}+C O M_{S G, n}+C L_{S G, n} \quad \text { (£/year) }
$$

where:

$C C_{S G, n} \quad$ capital cost of producing shale gas in year $n$ (£/year)

$C O M_{S G, n} \quad$ operating and maintenance costs of shale gas production in year $n$ (£/year)

$C L_{S G, n} \quad$ labour costs in year $n$ (£year).

The energy content of shale gas $E_{S G}$ produced over the lifetime of the well has been calculated using the estimated ultimate recovery (EUR) of gas over the lifetime of the well and the lower heating value (LHV) of shale gas: 
$E_{S G}=E U R \times L H V$

where:

EUR

estimated ultimate recovery of shale gas over the lifetime of the well $\left(\mathrm{m}^{3}\right)^{1}$

LHV lower heating value of shale gas $\left(40.82 \mathrm{MJ} / \mathrm{m}^{3}=11.3 \mathrm{kWh} / \mathrm{m}^{3}\right)$.

The EUR has been determined using a hyperbolic decline function for shale gas production as follows (Symmons et al., 2010):

$E U R=\sum_{m=1}^{M}\left(\frac{q_{i}}{\left(1+b D_{i} m\right)^{1 / b}}\right)$

where:

$q_{i} \quad$ initial shale gas production (in month one) at standard temperature and pressure $\left(\mathrm{m}^{3}\right)$

$b \quad$ Arps decline exponent (-)

$D_{i} \quad$ initial decline constant $\left(\right.$ month $\left.^{-1}\right)$

$m \quad$ month $m$ (month)

M total number of months over the lifetime of the well (months).

Therefore, combining equations (1)-(4), the total life cycle costs of shale gas production are equal to:

$L C C_{S G}=\frac{\sum_{n=1}^{N} C_{S G, n}}{E_{S G}}=\frac{\sum_{n=1}^{N}\left(C C_{S G, n}+C O M_{S G, n}+C L_{S G, n}\right)}{\sum_{m=1}^{M}\left(\frac{q_{i}}{\left(1+b D_{i} m\right)^{1 / b}}\right) \times L H V} \times 10^{2} \quad$ (pence/kWh)

It should be noted that $L C C_{S G}$ is not equivalent to the price that shale gas is sold at or the cost of fuel to the power plant; the former is discussed below and the latter in section 2.2.2.

The price at which shale gas can be sold will be affected by different market factors, including costs of production ( $L C C_{S G}$ ), tax and time value of money, which in turn will affect its economic feasibility. The latter has been evaluated by estimating the net present value (NPV) of the total expected cash flow and revenue to the shale gas producer. These have been used to estimate the price at which shale gas can be sold, together with the associated tax earnings for the government and the related contribution to the economy. A discounted cash flow analysis has been used for these purposes with the NPV calculated according to the following equation (Towler and Sinnot, 2008):

$N P V_{S G}=\sum_{n=1}^{N} \frac{\left(N E_{S G, n}+D_{S G, n}-C_{S G, n}\right)}{(1+i)^{n}}$

where:

$N P V_{S G} \quad$ net present value of total expected value of shale gas production ( $($ )

$N E_{S G, n} \quad$ net earnings from shale gas in year $n$ after tax ( $£ /$ year)

$D_{S G, n} \quad$ depreciation in year $n$ (£/year)

$i \quad$ discount rate for shale gas (-).

The net earnings $N E_{S G, n}$ in year $n$ have been estimated based on the gross revenue from shale gas and depreciation in that year, taking into account the current tax on shale gas of 30\% (HM Treasury, 2013):

$N E_{S G, n}=\left(R_{S G, n}-D_{S G, n}\right) \times\left(1-t_{r}\right) \quad$ (£/year $)$

\footnotetext{
${ }^{1}$ All references to the volume of gas are for the standard temperature and pressure, expressed as $\mathrm{Nm}^{3}$ (normal cubic metres). For simplicity, "N" is not used in the notation.
} 
where:

$R_{S G, n}$ gross revenue from shale gas in year $n$ (£/year)

$D_{S G, n} \quad$ depreciation in year $n$ (£/year)

$t_{r} \quad$ tax rate $(0.3)$.

The gross revenue $R_{S G, n}$ in year $n$ is equal to the volume of gas produced in year $n$, multiplied by the LHV and the price $p$ at which the gas is sold in that year:

$R_{S G, n}=V_{S G, n} \times L H V \times p$

where:

$V_{S G, n} \quad$ volume of shale gas produced in year $n\left(\mathrm{~m}^{3} /\right.$ year)

$p \quad$ unit price at which gas is sold (pence/kWh).

The value of $p$ at which the $N P V_{S G}$ is equal to zero is the break-even gas price $p$, which has been used to assess the competiveness of shale gas in the gas market. The above equations have also been applied to determine conditions for which shale gas production would be profitable.

The depreciation $D_{S G, n}$ in year $n$ is equal to:

$D_{S G, n}=d_{n} \times t_{d}$

$(£ /$ year $)$

where:

$d_{n} \quad$ the depreciable basis in year $n$ (value of assets minus salvage value) ( $£ /$ year)

$t_{d} \quad$ depreciation tax allowance rate (0.025).

\subsubsection{Costs of electricity generation}

The life cycle costs of electricity generation, also known as levelised electricity costs, have been calculated as follows (DECC, 2013a):

$\begin{array}{ll}L C C_{E}=\frac{N P V_{E C}}{N P V_{E G}} \times 10^{2} & \text { (pence } / \mathrm{kWh})\end{array}$

where:

$L C C_{E}$ life cycle costs of electricity generation (pence/kWh)

$N P V_{E C}$ net present value of total expected costs of electricity generation (£)

$N P V_{E G}$ net present value of expected electricity generation over the lifetime of the plant (kWh).

The NVP of the total expected costs of electricity generation is equal to:

$N P V_{E C}=\sum_{k=1}^{K} \frac{\left(C C_{E, k}+C O M_{E, k}+C F_{E, k}+C C O_{2 k}\right)}{(1+r)^{k}}$

where:

$C C_{E, k} \quad$ capital cost of the power plant in year $k$ ( $£ /$ year)

$C_{E, k} \quad$ operating and maintenance costs (including labour costs) of electricity generation in year $k$ ( $£ /$ year)

$C_{E, k} \quad$ cost of fuel to the power plant in year $k$ ( $£ /$ year)

$\mathrm{CCO}_{2 k} \quad$ cost to the power plant of emitting $\mathrm{CO}_{2}$ in year $k$ ( $($ year)

$r$

discount rate for the power plant (-)

$k$

year $k$

$K \quad$ lifetime of the power plant (years). 
The cost of shale gas to the power plant has been estimated based on the price $p$ at which shale gas production is profitable, calculated according to equations (5)-(9), plus other relevant costs; for further details, see section 2.2.1. This price has been varied through a sensitivity analysis to determine a range of profitable conditions.

The NPV of expected electricity generation over the lifetime of the plant has been calculated as:

$N P V_{E G}=\sum_{k=1}^{K} \frac{E_{k}}{(1+r)^{k}}$

where:

$E_{k} \quad$ net electricity generation in year $k(\mathrm{kWh} / \mathrm{yr})$.

Thus, merging equations (10)-(12), the total LCC or levelised costs of electricity generation are equal to:

$L C C_{E}=\sum_{k=1}^{K}\left(\frac{C C_{E, k}+C O M_{E, k}+C_{E F, k}+C C O_{2}}{E_{k}}\right) \times 10^{2} \quad$ (pence/kWh)

\subsection{Data and assumptions}

\subsubsection{Shale gas production}

The costs of bringing a shale gas well into operation and maintaining its production are given in Table 3 and Table S1 in the Supplementary Information (SI); they comprise the following:

- capital: cost of equipment and materials needed to bring a shale gas well into operation, including the costs of:

o seismic testing to determine the site geology;

$\circ$ pre-licencing and enabling, including planning and consent;

- exploration and appraisal to determine if a well is viable;

o drilling and completion;

- hydraulic fracturing;

- water and waste transport, storage and disposal;

o decommissioning of the well, including cement plugging and end-of-life and after-life monitoring;

- initial lump-sum payment to host communities, known as the "community charter", which is compulsory in the UK (Cronin, 2013);

o other costs, such as pad preparation, security, etc.;

- operating and maintenance (O\&M): cost of equipment and materials needed to maintain the well during production and annual payments to host communities as part of the community charter, amounting to $1 \%$ of the annual revenue from the sales of shale gas; and

- labour: wages paid to employees involved in the life cycle of a shale well, from predevelopment to decommissioning.

As there is no current commercial production of shale gas in the UK, the volume of gas produced over the lifetime of a well is based on US data for 2386 wells (SONRIS, 2013). Low, average and high EURs, estimated at 10,122 and $1260 \mathrm{Mm}^{3}$, respectively (Cooper et al., 2014), have been considered to determine the expected ranges of $L C C_{S G}$ and $p$. The wells have an assumed production lifespan of 30 years (Smil, 2015) and are assumed to require two years of pre-development activity to bring them into operation (DECC, 2013b; House of Lords, 2014). The discount rate has been assumed at $10 \%(i=0.1)$ which is the minimum acceptable rate of return for natural gas projects (Duman, 2012; Moniz et al., 
2011). The depreciation tax allowance is $2.5 \%\left(t_{d}=0.025\right)$ and government tax $30 \%\left(t_{r}=0.3\right)$ (HM Treasury, 2013). The depreciable basis $d_{n}$ in year $n$ is assumed to be equal to the expenditure in that year.

The NPV has been used to determine the payback period for shale gas projects as well as the effect of gas prices on the profitability. The latter is explored through a sensitivity analysis by calculating the NPV for a fixed discount rate of $10 \%$ for a range of gas prices (selected arbitrarily to cover a reasonably broad region). The influence on the results of different discount rates is also explored in the sensitivity analysis by calculating the breakeven price required at different discount rates, as well as how the latter affect fuel costs to the power plant. The estimated break-even prices have been assumed equal to the wholesale market prices to allow comparison with other gas options (conventional natural gas $^{2}$ and US shale gas) and enable the estimation of fuel costs to the power plant. These assumptions have been made due to a lack of data on additional charges for shale gas entering the gas market (e.g. charges by gas traders, analysts, etc.) and the price it would be traded at, as well as the profit margins of shale gas operators. In reality, market prices will be higher than the break-even values.

Forty wells have been assumed per pad, producing methane only, with natural gas liquids not considered. The latter have proven to be an important contributor to the overall economic viability of wells in the US, as heavier hydrocarbons are more valuable (FT, 2016). However, without information on the type and volume of gas liquids found in UK shale plays, it is not possible to speculate on the amount that may be produced. Mineral royalties would also be payable, but this is charged on the tax paid (portion of taxable income taxed at a lower rate) and can be subject to relief under tax treaties (Deloitte, 2013; HM Revenues and Customs, 2011). As it is uncertain what tax treaties and lower tax rates would be applied (if any), mineral royalties are not included in the NPV analysis.

Table 3: Costs of shale gas production (Amion, 2014; Cronin, 2013; Lewis et al., 2014; Taylor and Lewis, 2013).

\begin{tabular}{|c|c|c|}
\hline Cost category & Description & $\begin{array}{l}\text { Cost per well } \\
\text { (M£) }\end{array}$ \\
\hline \multicolumn{3}{|l|}{ Capital } \\
\hline Seismic testing & 3D imaging to determine geological characteristics & 0.02 \\
\hline Pre-licensing and enabling & Preparation to secure site (planning permission, etc.) & 0.01 \\
\hline Exploration and appraisal & Well exploration and testing & 1.50 \\
\hline Drilling and completion & Equipment, materials, etc. & 2.07 \\
\hline Hydraulic fracturing & Equipment, materials, etc. & 5.14 \\
\hline Storage and transportation & Waste and water transportation and storage & 0.32 \\
\hline Waste disposal & Waste management and treatment & 0.69 \\
\hline Decommissioning & Plugging and other end-of-life activities & 0.28 \\
\hline Community charter $^{\mathrm{a}}$ & Initial lump-sum payment to hosting communities & $2.50 \times 10^{-3}$ \\
\hline Other & $\begin{array}{l}\text { Pad preparation, security, gas collecting and } \\
\text { processing, equipment, pipelines and road access }\end{array}$ & 0.13 \\
\hline Operation and maintenance ${ }^{b}$ & Operation and maintenance & 1.50 \\
\hline Labour & Staffing & 6.30 \\
\hline
\end{tabular}

\footnotetext{
2 'Conventional' natural gas refers to gas extracted using conventional techniques, as opposed to shale gas which is considered an 'unconventional' fuel source. Conventional gas includes both gaseous and liquefied natural gas (LNG).
} 


\subsubsection{Electricity generation}

The power plant data are summarised in Table 4 and Table 5. It is assumed that shale gas is used in a combined cycle gas turbine (CCGT) power plant, the prevalent gas technology in the UK (BEIS, 2016b). As mentioned earlier, the cost of shale gas to the power plant $C F_{E}$ has been calculated based on the price $p$ it can be sold at, estimated from equations (5)-(9), plus additional costs, such as gas distribution, value added tax (VAT) and climate change levy (Table 6). Shale gas is assumed to be sold at its break-even price, because of the uncertainty and a lack of data on profit margins for shale gas production. It is also assumed that power plants buy the fuel directly from shale gas companies, using the national grid for distribution to the power plant. These are conservative assumptions as gas would probably not be sold at the break-even price and the additional costs to the power plant may be affected by many different factors, including carbon price and any government incentives. Furthermore, the power plant will more likely buy gas through gas traders than directly from the shale gas operator. However, in the absence of actual data, these assumptions are deemed reasonable, particularly as a wide range of prices and costs are considered in the sensitivity analysis.

The lifetime of the power plants has been assumed at 25 years (Parsons Brinckerhoff, 2013) and the discount rate of $10 \%(r=0.1)$ (DECC, 2013a). Note that shale gas costs and annual electricity generation have been fixed for the lifetime of the power plant as is common in estimations of the LCC of electricity (DECC, 2013a; Parsons Brinckerhoff, 2013; Mott MacDonald, 2010).

Table 4: Specification of the CCGT power plant ${ }^{\text {a }}$ (Mott MacDonald, 2010; Parsons Brinckerhoff, 2013).

\begin{tabular}{lr}
\hline Variable & Value \\
\hline Installed capacity (MW) & 900 \\
Capacity factor $(-)$ & 0.928 \\
Plant efficiency $(\%)$ & 53 \\
Low heating value of gas $\left(\mathrm{kWh} / \mathrm{m}^{3}\right)$ & 11.3 \\
Net power generation $(\mathrm{TWh} / \mathrm{yr})$ & 7.32 \\
$\mathrm{CO}_{2}$ emissions $(\mathrm{g} / \mathrm{kWh})$ & $347^{\mathrm{b}}$
\end{tabular}

${ }^{a}$ Due to a lack of data on future CCGT specifications, the same CCGT specification has been used for current and 2030 estimates.

${ }^{\mathrm{b}}$ Based on the emission of $184 \mathrm{~g} \mathrm{CO}_{2} / \mathrm{kWh}$ of gas when combusted and the efficiency of CCGT of $53 \%$.

Table 5: Costs of CCGT power plants ${ }^{a}$ (Mott MacDonald, 2010; Parsons Brinckerhoff, 2013).

\begin{tabular}{llll}
\hline Cost category & Low & Medium & High \\
\hline Capital (M£) & 454 & 541 & 636 \\
$\begin{array}{l}\text { Operation and maintenance (£/MW } \mathrm{yr}) \\
\quad\end{array}$ & 26,000 & 31,000 & 36,000 \\
$\quad$ Fixed $^{D}$ & $0^{\mathrm{C}}$ & 651 & 1220 \\
$\mathrm{VO}_{2}(£ / \mathrm{t})$ & $0^{\mathrm{d}}$ & 54.30 & 135.00 \\
\hline
\end{tabular}

${ }^{a}$ Due to a lack of data for future CCGT costs, the same costs have been assumed for the current and 2030 estimates.

${ }^{\mathrm{b}}$ Fixed costs: labour, materials and equipment. Variable costs: repairs.

${ }^{\mathrm{c}}$ No overhauls or equipment/components replacements.

${ }^{\mathrm{d}} \mathrm{No}$ costs charged for $\mathrm{CO}_{2}$ emissions.

Table 6: Various costs to the operator of power plants (HM Revenues and Customs, 2016b; HM Revenues and Customs, 2016a; National Grid, 2016).

\begin{tabular}{ll}
\hline Cost category & Value \\
\hline Transmission and distribution & 0.0951 pence/kWh \\
Value added tax (VAT) & $20 \%$ of the price of gas paid by the operator \\
Climate change levy & 0.195 pence/kWh \\
\hline
\end{tabular}




\subsubsection{Future gas and electricity scenarios}

As mentioned in Section 2.1, in addition to estimating the present LCC of shale gas and its electricity, a medium-term future up to 2030 is also considered in this work. The assumed UK gas mix in 2030 is shown in Table 7, together with the range of gas prices. These values have been used to estimate the cost of gas to the power plant, $C F_{E}$, relative to their contribution to the gas mix. These estimated values are assumed to represent the wholesale fuel prices and have been used to calculate the $L C C_{E}$ of electricity generated from the 2030 gas mix. Two scenarios are considered for the future mix (Table 7): 'low' refers to a minimum and 'high' to a maximum expected production of shale gas in 2030 (Cooper et al., 2014; Williams et al., 2011), assuming all shale gas produced is used domestically.

The 2030 electricity mix can be found in Table 8, alongside the LCC of different electricity options and their contribution to the mix which have been used to estimate the LCC of electricity in 2030. The LCC costs have then been used to estimate the cost of electricity to the consumer (wholesale, excluding tax and other costs) assuming an average annual domestic consumption of $3200 \mathrm{kWh}$ per household (Villalobos, 2013). As indicated in Table 8, three scenarios for electricity generation have been considered (DECC, 2013c): 'best', which assumes a high penetration of renewable electricity and a large drop in coal generation; 'worst', with a lower penetration of renewables and a higher contribution from coal; and 'central', representing an intermediate of the two scenarios. It is also assumed that the CCGT power plant will have the same capacity and efficiency in 2030 as the current technology (see Table 4) due to a lack of data for future development of CCGT. However, as CCGT is a well-established technology, this is deemed a reasonable assumption.

Table 7: Assumed gas prices and contribution of different sources to the gas mix in 2030

\begin{tabular}{|c|c|c|c|c|c|}
\hline \multirow[t]{2}{*}{ Gas source } & \multicolumn{3}{|c|}{ Gas price (pence/kWh) } & \multicolumn{2}{|c|}{$\begin{array}{l}\text { Gas production (bn } \mathrm{m}^{3} \text { ) } \\
\text { (Contribution to the gas mix (\%)) }\end{array}$} \\
\hline & Low & Medium & High & Low $^{\mathrm{D}}$ & $H i g h$ \\
\hline European pipeline import $^{a}$ & 1.61 & 1.99 & 2.38 & $43(48.9)$ & $43(48.9)$ \\
\hline LNG import $^{\mathrm{a}}$ & 1.66 & 1.97 & 2.19 & $25(28.4)$ & $4(4.5)$ \\
\hline UK North Sea ${ }^{a}$ & 1.42 & 1.76 & 2.00 & $16(18.2)$ & $16(18.2)$ \\
\hline UK shale gas ${ }^{c}$ & - & - & - & $4(4.5)$ & $25(28.4)$ \\
\hline
\end{tabular}

Table 8: Assumed life cycle (levelised) costs and electricity generation by source in 2030.

\begin{tabular}{|c|c|c|c|c|}
\hline \multirow[t]{2}{*}{ Electricity source } & \multirow[t]{2}{*}{$\begin{array}{c}\text { Cost } \\
{\text { (pence } / k W h)^{a}}^{a}\end{array}$} & \multicolumn{3}{|c|}{$\begin{array}{l}\text { Electricity generation (TWh/yr) } \\
\text { (Contribution to the grid (\%)) }\end{array}$} \\
\hline & & Best $^{\mathrm{b}}$ & Central $^{\mathrm{b}}$ & Worst $^{\text {b }}$ \\
\hline Coal & 13.85 & $1.86(0.49)$ & $1.86(0.49)$ & $4.20(1.12)$ \\
\hline Gas & & $87.10(22.77)$ & 84.50 (22.37) & $77.50(20.67)$ \\
\hline CCS & 12.35 & $32.70(8.55)$ & $33.30(8.82)$ & $33.90(9.04)$ \\
\hline Nuclear & 7.70 & $101.90(26.64)$ & $102.00(27.01)$ & $101.80(27.15)$ \\
\hline Renewables (average) $^{d}$ & 10.53 & $159.00(41.55)$ & $156.00(41.31)$ & $157.50(42.02)$ \\
\hline Total & & $382.56(100)$ & $377.66(100)$ & $374.90(100)$ \\
\hline \multicolumn{5}{|c|}{$\begin{array}{l}\text { a Sources: BEIS (2016c), DECC (2013a). } \\
\text { b } \text { Best: high penetration of renewables and low contribution from coal; worst: lower penetration of renewables and } \\
\text { a bigger contribution from coal; central: an intermediate case between 'best' and 'worst' (DECC, 2013c). } \\
\left.{ }^{c} \text { Calculated as part of this work (Section } 3.5 .2 .1\right) \text {. } \\
\text { d Solar PV: } 6.70 \text { pence/kWh; wind: } 9.73 \text { pence/kWh; biomass (woodchips): } 11.75 \text { pence/kWh; hydropower: } 14.60 \\
\text { pence/kWh (BEIS, 2016c; DECC, } 2013 \mathrm{a}) \text {. }\end{array}$} \\
\hline
\end{tabular}




\section{Results and discussion}

\subsection{Life cycle costs of shale gas}

Based on the data in Table 3, it would cost £17.96 $\mathrm{M}$ to bring a single well into operation and maintain production over 30 years. The capital and labour costs make up the majority (92\%) of the total cost. Half of the capital costs, estimated at $£ 10.16$ million, are due to hydraulic fracturing, which in turn is largely due to equipment (83\%); for a detailed breakdown of costs, see Table S1 in the SI. By comparison, hydraulic fracturing equipment in the US makes up only $35 \%$ of capital costs (Bonakdarpour et al., 2011). The reason for the higher cost in the UK is because of the need to import technology (high power portable blenders and high power fracturing pumps) and expertise from the US.

The labour costs, estimated at $£ 6.3 \mathrm{M}$ over the whole life cycle of the well, contribute $35 \%$ to the total well costs. The total number of jobs per well over its lifetime is relatively small: 17.5 full-time equivalents, of which four jobs are for pre-development, 13 for pad preparation and 0.5 for production (estimated using data from AMEC (2013) and Lewis et al. (2014). However, the labour costs are high because of the high salaries in the oil and gas sector. On average, oil and gas workers earn between $£ 36,000$ and $£ 160,000$ per year, which is $34 \%$ to six times above the UK national average (Lewis et al., 2014; ONS, 2013). Also, the jobs created during the production stage are long term, which contributes to the high labour costs.

The remaining $8 \%$ of the well costs is due to the operating and maintenance costs ( $£ 1.5 \mathrm{M})$. However, this excludes the payment of $1 \%$ of the revenue from shale gas as part of the community charter, as noted in Table 3 . Based on the average EUR and the NPV estimated by eqns. (4) and (6), this cost to the operator ranges between $£ 351,000-£ 665,000$ per well, increasing the total operating and maintenance costs to up to £2.16 $\mathrm{M}$ and the total costs per well to up to $£ 18.63 \mathrm{M}$. The payments to host communities as a result of the community charter projected by UKOOG (2013) are in the region of $£ 125,000-£ 250,000$ per well; up to $64 \%$ lower than the estimates in this study. This difference is largely due to the different EURs assumed, with UKOOG using the values from Taylor and Lewis (2013) which are lower than the EURs in this study as they were based on data from US shale plays producing both gas and oil. The data in this study exclude oil production because the UK Bowland-Hodder shale play is expected to produce only natural gas. Furthermore, UKOOG did not state the gas prices they used so it is not possible to compare the results more closely.

Based on the above well costs and equations (1)-(5), the estimated life cycle costs of shale gas production $L C C_{S G}$ range widely, from $0.13-15.76$ pence/kWh (0.47-56.74 pence/MJ); this is due to the wide range of EUR considered (see section 2.3.1). As shown in Table 9, for the average EUR, the costs are equal to 1.29 pence/kWh (4.64 pence/MJ). The life cycle costs of shale gas production $L C C_{S G}$ are compared in the next section to the prices $p$ at which it can be sold economically, estimated through the NPV analysis.

Table 9: Estimated life cycle costs for the break-even prices of shale gas at $10 \%$ discount rate.

\begin{tabular}{llcl}
\hline Cost category & \multicolumn{3}{c}{ Shale gas costs (pence/kWh) } \\
& Low $^{a}$ & Average $^{a}$ & High $^{a}$ \\
\hline Break-even price of shale gas $(p)$ & 0.26 & 2.63 & 31.79 \\
Life cycle costs of shale gas $\left(\angle C C_{S G}\right)$ & 0.13 & 1.29 & 15.76 \\
\hline a & & &
\end{tabular}

a Low: high EUR; high: low EUR; average: average EUR.

\subsection{Net present value and break-even price of shale gas}

As explained in Section 2.2.1, the economic feasibility of shale gas production has been evaluated using a discounted cash flow analysis to estimate the NPV and break-even price 
of shale gas (eqns. (6)-(9)). The results are summarised in Figure 2, assuming a discount rate of $10 \%$. The former indicates that the minimum (wholesale) price $p$ at which shale gas can be sold to break-even must exceed 2.63 pence/kWh (9.47 pence/MJ) for the average EUR but the break-even point only occurs at the end of the well's lifetime. For the high and low EURs, the break-even prices are 0.26 and 31.79 pence/kWh (0.95-114.44 pence/MJ), respectively (Table 9).

At higher shale gas prices, the break-even point is achieved sooner and the exploitation becomes profitable. For example, at 2.70 pence/kWh, the well breaks even in year 19 with the total NPV of $£ 0.3 \mathrm{M}$ at the end of 30 years; at 3 pence/kWh, the NPV increases more than five-fold on the previous value (to $£ 1.68 \mathrm{M}$ ) and the project breaks even in year ten (Figure 2). If the gas can be sold at 5 pence $/ \mathrm{kWh}$, the project is profitable in year three and the NPV increases to $£ 10.89 \mathrm{M}$.

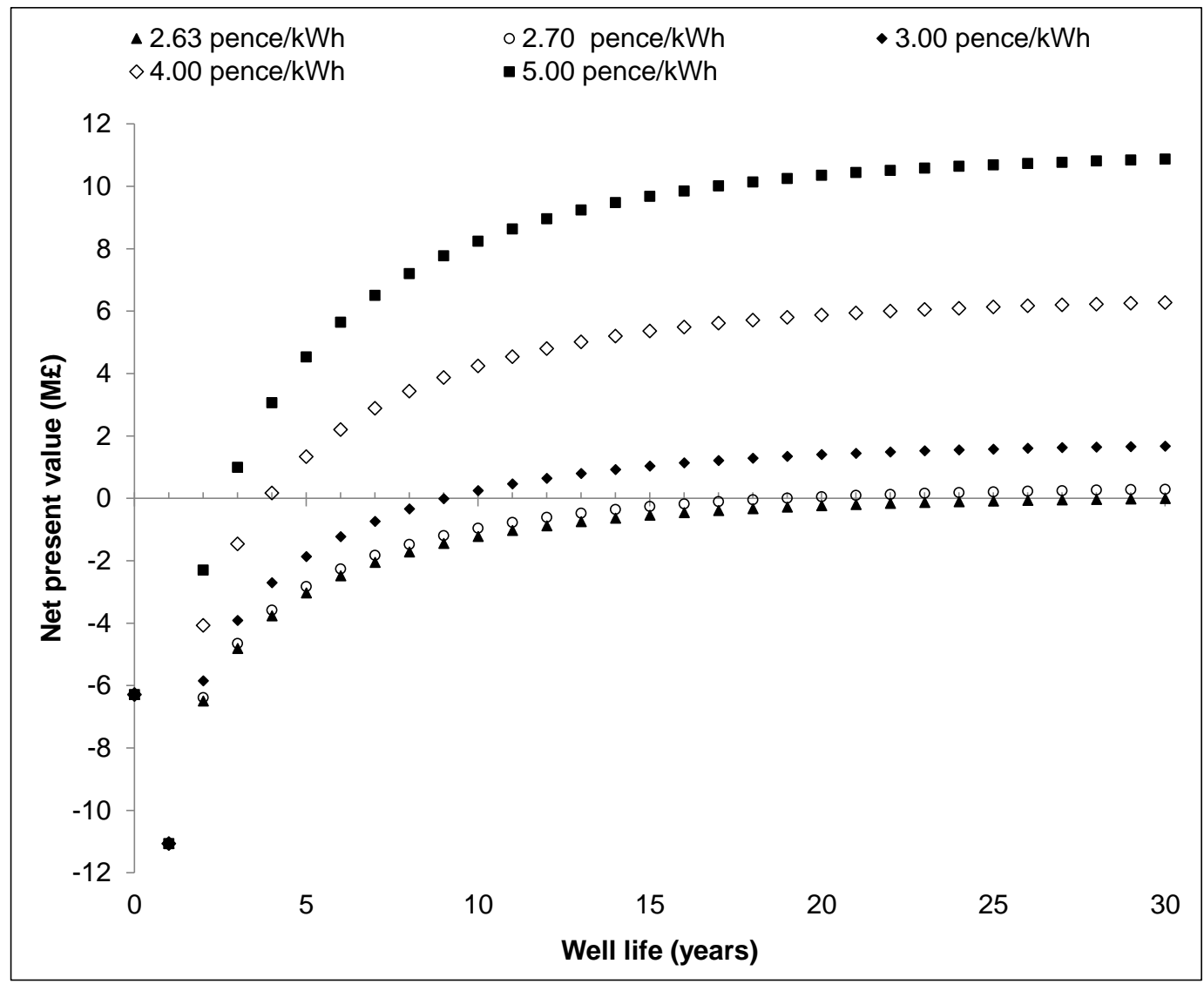

Figure 2: Net present values for different break-even gas prices over the lifetime of a well at $10 \%$ discount rate and the average EUR.

The estimated break-even prices for shale gas at the discount of $10 \%$ are compared in Figure 3 to the market prices of conventional gas in the UK and elsewhere as well as with the US shale gas. As can be seen, the average break-even price of shale gas is almost $50 \%$ higher than the price of gas traded in the UK Heren NBP and around twice the price of LNG imports (mainly from Qatar). The price of shale gas is also higher than any other gas considered here; the only exception is LNG from Japan, which is around $20 \%$ more expensive. In comparison to the break-even price of US shale gas, UK shale gas is 2.5 times more expensive, but the value for the former is estimated at a $15 \%$ discount. Assuming the same rate for UK shale gas, it becomes even more expensive (3.13 vs 1.09 pence/kWh for US shale gas). These results suggest that UK shale gas is not competitive with either 
domestic or imported conventional gas and is unlikely it will help to reduce energy prices in the UK.

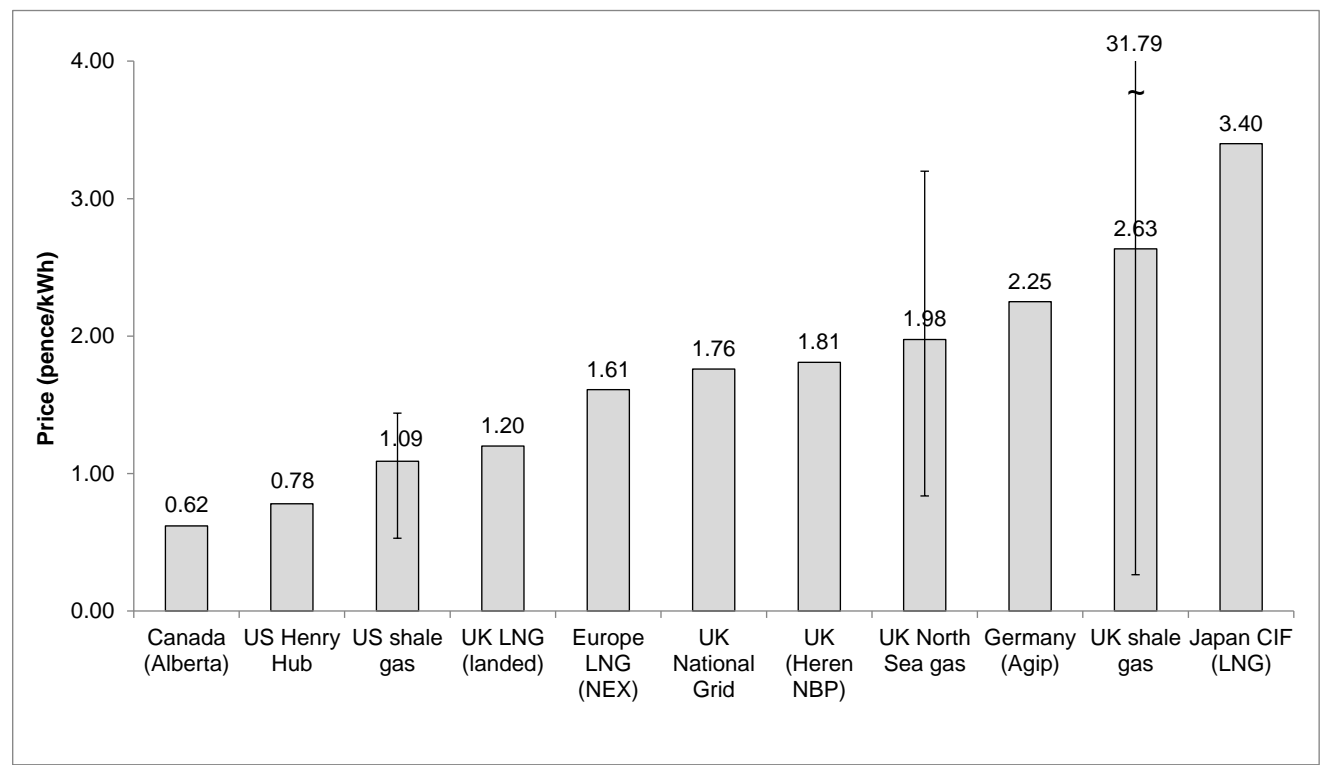

Figure 3: Comparison of the break-even price of UK shale gas to market prices of US shale gas and conventional gas in the UK and elsewhere.

[Shale gas: break-even price estimated in this work at 10\% discount rate. The error bars represent high prices estimated at low EUR and vice versa. The values for US shale gas and UK North Sea gas are the break-even prices at $15 \%$ discount rate; the values for UK North Sea gas are for new projects (BNEF, 2013; Moniz et al., 2011; Oil \& Gas UK, 2010; Weijermars, 2013; Wexelstein, 2014; Berman and Pittinger, 2011). UK LNG (landed), Germany (Agip) and Japan CIF (LNG) are average prices; all others are spot market prices (BP, 2014; BP, 2016b; ICIS, 2014; Oil \& Gas UK, 2010; Wexelstein, 2014; FERC, 2017). CIF: Cost, insurance and freight.]

However, as indicated in Figure 4, the break-even price of shale gas is sensitive to the discount rate assumed, ranging from 1.72 pence/kWh for $1 \%$ to 4.60 pence $/ \mathrm{kWh}$ for $30 \%$. At $2 \%$, its price would be comparable to that of conventional gas traded at UK Heren NBP (1.82 vs 1.81 pence/kWh) and at $3 \%$ shale gas would be cheaper than UK North Sea gas. To match the trade price in the National Grid (1.76 pence/kWh), the discount rate would need to be reduced to $1.3 \%$ which, at the time of writing, is close to the UK's prime lending rate of 1.5\% (Trading Economics, 2017). However, as shale gas is a new industry, it is considered a high risk venture (Crooks, 2016; Weng and Hefley, 2016). Therefore it is highly unlikely that projects will be financed at such low rates. Finally, if a zero discount rate is assumed, shale gas would become competitive with LNG in Europe (see Figure 4). The above values refer to the average EUR; for the break-even prices for the low and high EURs, see Table S3 in the SI.

As far as we are aware, only one previous study estimated break-even prices of UK shale gas (BNEF, 2013), with the values ranging from 1.55-2.66 pence/kWh for a $15 \%$ discount rate. These values are $18 \%$ to two times lower than the estimate in this study for the same discount rate (3.13 pence/kWh). However, the BNEF study did not consider the community charter, labour and decommissioning costs. It also assumed the capital cost in the range of $£ 5-£ 7 \mathrm{M}$, which is lower than in this and other studies (Amion, 2014; Lewis et al., 2014; Taylor and Lewis, 2013).

It should be borne in mind that all estimates of shale gas prices and economic viability are uncertain, as they are based on the assumed rather than actual EUR values, which are currently unknown. However, a wide range of EUR has been considered in this work, spanning very low to very high values. Furthermore, the viability of shale gas will also depend on the price at which gas is traded in the National Grid and the price power plants 
pay for gas (for the latter, see Section 3.4), which are all influenced by demand. In recent years, natural gas consumption in power plants has declined as generation from renewables has increased (BEIS, 2016d). Nevertheless, the estimates suggest that shale gas cannot compete with conventional gas, including LNG, except at low discount rates.

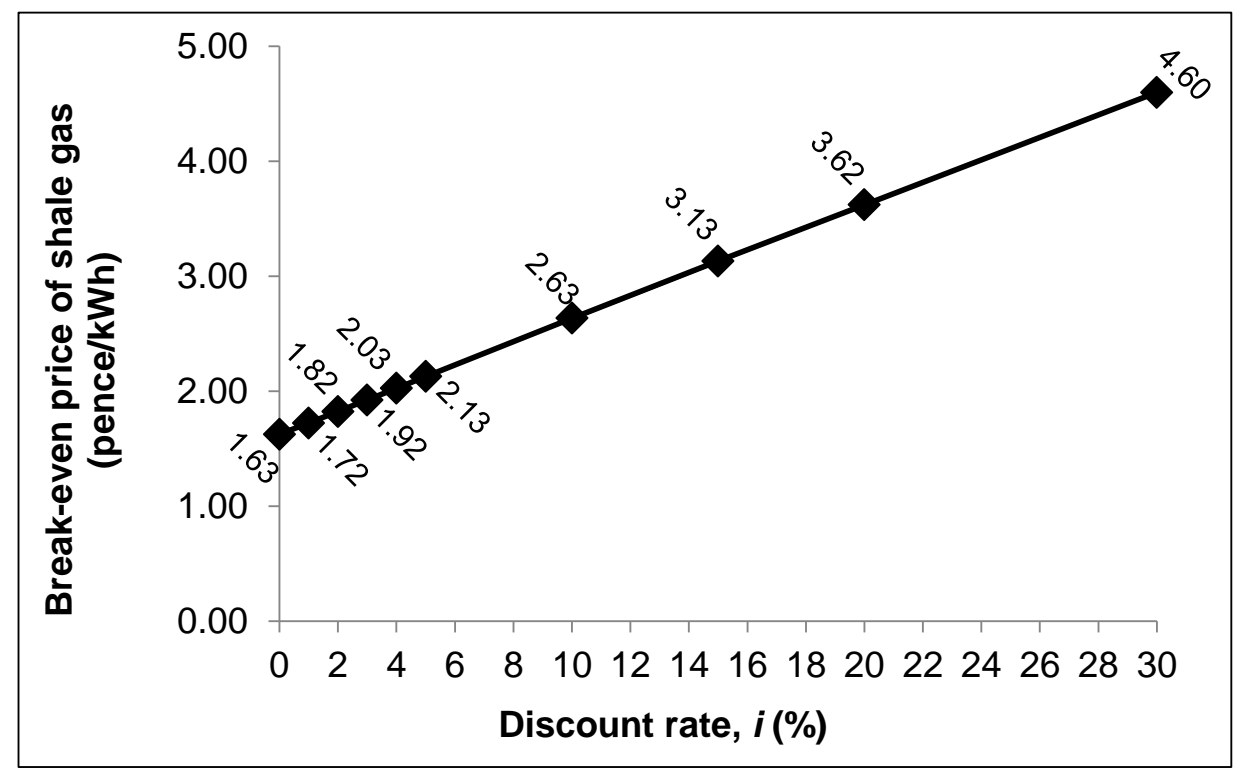

Figure 4: Break-even prices of shale gas for different discount rates at the average EUR.

\subsection{Economic impacts of shale gas}

In this section, the direct economic impacts of shale gas are discussed first, including operator's profit and the overall potential contribution to the economy. This is followed by potential indirect impacts on other industrial sectors.

\subsubsection{Direct economic impacts}

The estimated economic impact of a shale gas well on operator's profit and tax revenue to the government is shown in Table 10 for different gas prices. As can be seen, for the gas prices considered in Figure 2, the operator's revenue ranges from £35 M to £66.5 M per well over its lifetime. Based on these values, the payments to host communities as part of the community charter would be in the range from $£ 351,000$ to $£ 665,000$ over the lifetime of the well (as also mentioned in Section 3.1). In addition to this, the well would be contributing $£ 10.5-£ 20 \mathrm{M}$ in tax revenue. Assuming that 4000 shale gas wells will be drilled in the UK (Lewis et al., 2014), this could cumulatively generate $£ 42-£ 80$ billion in tax income for the government.

On an annual basis, the average operator's profit and tax revenue to the government would be equivalent to $£ 1.17-£ 2.22 \mathrm{M}$ and $£ 0.35-£ 0.665 \mathrm{M}$, respectively. It is predicted that up to 400 wells might be drilled per year during peak activity (Lewis et al., 2014). Based on this, shale gas could generate up to $£ 468-£ 888 \mathrm{M}$ in pre-tax annual profits for shale gas companies, contributing £328-£622 M annually (0.017\%-0.033\%) to the GDP of $£ 1872$ bn in 2015 (Statista, 2017). For context, the whole UK's oil and gas industry contributed $£ 24$ bn to the GDP in 2013 (BIS, 2015). Thus, this contribution of shale gas represents $1.4 \%-2.6 \%$ of the total sector's GDP contribution.

The operator's revenue during peak production would also generate $£ 141-£ 266 \mathrm{M}$ in annual tax revenue (based on the annual profits in Table 10 and 400 wells drilled annually). Again for context, tax revenue in the UK in 2015 totalled £670 bn (Office for Budget Responsibility, 
2016) so that the total contribution of shale gas to tax is equivalent to $0.02 \%-0.04 \%$. By comparison, shale gas in the US generated US $\$ 29$ bn in revenue to shale gas companies in 2010, contributing $0.2 \%$ to the GDP and US $\$ 10$ bn in tax revenue $(0.07 \%$ of GDP) (Fullenbaum et al., 2011; The World Bank, 2017). Therefore, the economic effect of shale gas on the UK economy would be significantly lower.

This can partly be explained by the fact that the scale of production is likely to be smaller in the UK than in the US. The scale of production can be measured by the well density, which is defined as the number of horizontal wells per area available for shale gas exploration and extraction. As mentioned earlier, it is estimated that 4000 horizontal wells will be drilled in the UK covering the area of 37,000 square miles, which gives a well density of 0.11 wells per square mile (Andrews, 2013; Lewis et al., 2014). In the US, the well density ranges from two to 11 wells per square mile, averaging at eight wells per square mile (EIA, 2011). Therefore, the scale and density of production in the UK would need to be much larger than currently envisaged to approach an impact on a national scale that is comparable to that in the US.

Table 10: Economic impacts of a shale gas well over its lifetime for different breakeven gas prices at $10 \%$ discount rate and average EUR.

\begin{tabular}{lcccc}
\hline $\begin{array}{l}\text { Gas price } \\
\text { (pence/kWh) }\end{array}$ & $\begin{array}{c}\text { Payback } \\
\text { period } \\
\text { (years) }\end{array}$ & $\begin{array}{c}\text { Operator's } \\
\text { revenue } \\
\text { before tax } \\
\text { (M£) }\end{array}$ & $\begin{array}{c}\text { Community } \\
\text { charter }^{\mathbf{a}} \\
\text { (M£) }\end{array}$ & $\begin{array}{c}\text { Tax @30\% } \\
\text { (M£) }\end{array}$ \\
\hline $2.63^{\mathrm{b}}$ & 30 & 35.06 & 0.35 & 10.52 \\
2.70 & 19 & 35.93 & 0.36 & 10.78 \\
3.00 & 10 & 39.92 & 0.40 & 11.98 \\
4.00 & 4 & 53.23 & 0.53 & 15.97 \\
5.00 & 3 & 66.54 & 0.67 & 19.96 \\
\hline a 1\% of revenue. &
\end{tabular}

\subsubsection{Indirect economic impacts}

In addition to the direct impacts on the UK economy, shale gas could have various indirect economic effects. Some of these would be on the sand and chemical sectors due to the significant amounts used for hydraulic fracturing (see Table S2 in the SI). It is estimated that some $9 \mathrm{Mt}$ of sand will be required over the time required to fracture hydraulically 4000 horizontal wells (15 years), which averages at around 600,000 t/yr (Lewis et al., 2014). To put this into context, in 2012 the UK consumed 26 Mt of sand for glass making, metals casting, construction, etc. (Bide et al., 2014). Thus, the average yearly sand requirement for shale gas extraction corresponds to around $2.3 \%$ of 2012 consumption. Based on the values in Table 3 and Table S1, shale gas could generate $£ 2$ bn in revenue for sand producers across the 4000 wells or $£ 200 \mathrm{M}$ per year during peak activity, equivalent to $0.3 \%$ of the sand industry’s annual income of £60.3 billion in 2012 (Bide et al., 2014).

Chemicals used to enhance the performance of the fracturing fluid (e.g. friction reducers, stabilisers, biocides, etc.) typically make up around $0.1 \%$ vol. of the fluid (Cuadrilla Resources, 2017a); for details, see Table S2 in the SI. It is estimated that the use of chemicals for shale gas extraction in the UK could be worth $£ 187,000$ per horizontal well or $£ 748 \mathrm{M}$ for 4000 wells (Lewis et al., 2014). This would contribute $0.2 \%$ annually to the total UK chemicals industry's turnover, reported at £42.97 bn in 2010 (ONS, 2010).

Therefore, shale gas development is unlikely to help boost the chemicals and sand industries. Despite this, there could be an increase in employment in these two sectors to meet the increase in demand for sand and chemicals. 


\subsection{Life cycle costs of electricity from shale gas}

The life cycle costs of electricity $L C C_{E}$ generated from shale gas depend, among others, on the cost of shale gas $C F_{E}$ to the power plant, which in turn depends on the discount rate and the EUR. As can be seen in Table 11, the $L C C_{E}$ estimated using eqn. (10), range from 2.02132.25 pence $/ \mathrm{kWh}$ for the discount rates of $5 \%-30 \%$. For the medium power plant costs and average EUR, the $L C C_{E}$ vary from 8.42-14.04 pence/kWh. For the low plant costs and high EUR, the $L C C_{E}$ is significantly lower $(2.02-2.56$ pence/kWh), while for the high plant costs and low EUR, it is much higher (64.78-132.25 pence/kWh).

These estimates are compared to the $L C C_{E}$ of other sources of electricity in Figure 5 for the $10 \%$ discount rate. At low costs (see Table 11 for details) shale gas electricity is much cheaper than the other electricity options considered. However, for the medium conditions, shale gas electricity is $17 \%$ more expensive than that from domestic conventional gas (9.59 vs 8 pence $/ \mathrm{kWh}$ ) and $20 \%$ more expensive than electricity from imported LNG. Nevertheless, it is still more competitive than most other electricity options, except for nuclear which has costs similar to UK conventional gas. In the worst case, however, the LCC of shale gas electricity are ten times higher than that generated using conventional gas and almost five times greater than the costs of the most expensive option, solar PV.

At a discount rate of $5 \%$ and assuming medium LCC (8.42 pence/kWh), electricity from shale gas is comparable to that from UK conventional gas and nuclear power and it is cheaper than coal and all the renewables considered here (see Table 11 and Figure 5).

Figure 5 also shows that the LCC of shale gas electricity is mostly influenced by fuel costs. As indicated in Table 11, fuel costs contribute 50\%-61\% to the total for the low costs, $63 \%$ $78 \%$ for the medium and $91 \%-95 \%$ for the high. By comparison, fuel costs for conventional gas electricity contribute around $60 \%$ to the total, which is comparable to the lower range $(62 \%)$ for the medium costs of shale gas electricity.

Therefore, these results suggest that shale gas electricity could be competitive with other electricity options in terms of life cycle costs. However, this is highly dependent on the fuel cost to the power plant, which is in turn dependent on the discount rate and the EUR.

Table 11: Life cycle (levelised) cost of shale gas electricity for different shale gas prices and power plant costs.

\begin{tabular}{llrrrrr}
\hline $\begin{array}{l}\text { Cost category } \\
\text { (pence/kWh) }\end{array}$ & Power plant & \multicolumn{3}{c}{ Discount rate (fuel) } \\
\hline Capital & costs and EUR & & & & \\
& Low & $5 \%$ & $10 \%$ & $15 \%$ & $20 \%$ & $30 \%$ \\
& Medium & 0.68 & 0.68 & 0.68 & 0.68 & 0.68 \\
& High & 0.81 & 0.81 & 0.81 & 0.81 & 0.81 \\
Operating \& & Low & 0.96 & 0.96 & 0.96 & 0.96 & 0.96 \\
maintenance & Medium & 0.32 & 0.32 & 0.32 & 0.32 & 0.32 \\
& High & 0.39 & 0.39 & 0.39 & 0.39 & 0.39 \\
Fuel $^{\mathrm{D}}$ & Low & 0.46 & 0.46 & 0.46 & 0.46 & 0.46 \\
& Medium & 1.02 & 1.13 & 1.24 & 1.35 & 1.56 \\
& High & 5.34 & 6.51 & 7.64 & 8.75 & 10.96 \\
$\mathrm{CO}_{2}$ & Low & 58.67 & 72.52 & 86.09 & 99.46 & 126.14 \\
& Medium & 0 & 0 & 0 & 0 & 0 \\
& High & 1.88 & 1.88 & 1.88 & 1.88 & 1.88 \\
& Low & 4.69 & 4.69 & 4.69 & 4.69 & 4.69 \\
\hline Total life cycle & Medium & $\mathbf{2 . 0 2}$ & $\mathbf{2 . 1 3}$ & $\mathbf{2 . 2 4}$ & $\mathbf{2 . 3 5}$ & $\mathbf{2 . 5 6}$ \\
cost (LCC & E) & $\mathbf{8 . 4 2}$ & $\mathbf{9 . 5 9}$ & $\mathbf{1 0 . 7 2}$ & $\mathbf{1 1 . 8 3}$ & $\mathbf{1 4 . 0 4}$ \\
& High & $\mathbf{6 4 . 7 8}$ & $\mathbf{7 8 . 6 3}$ & $\mathbf{9 2 . 2 0}$ & $\mathbf{1 0 5 . 5 7}$ & $\mathbf{1 3 2 . 2 5}$ \\
\hline
\end{tabular}

\footnotetext{
a "Low": low power plant costs (Table 5) and high EUR (1260 $\left.\mathrm{Mm}^{3}\right)$; "Medium": medium power plant costs (Table 5) and average EUR (122 $\left.\mathrm{Mm}^{3}\right)$; "High": high power plant costs (Table 5) and low EUR $\left(10 \mathrm{Mm}^{3}\right)$.

${ }^{\mathrm{b}}$ Cost of shale gas to the power plant, calculated by summing up the break-even (assumed as wholesale) shale gas prices (see Table S3 in the SI) and the additional costs to the power plant, discounted over time (Table 6).
} 


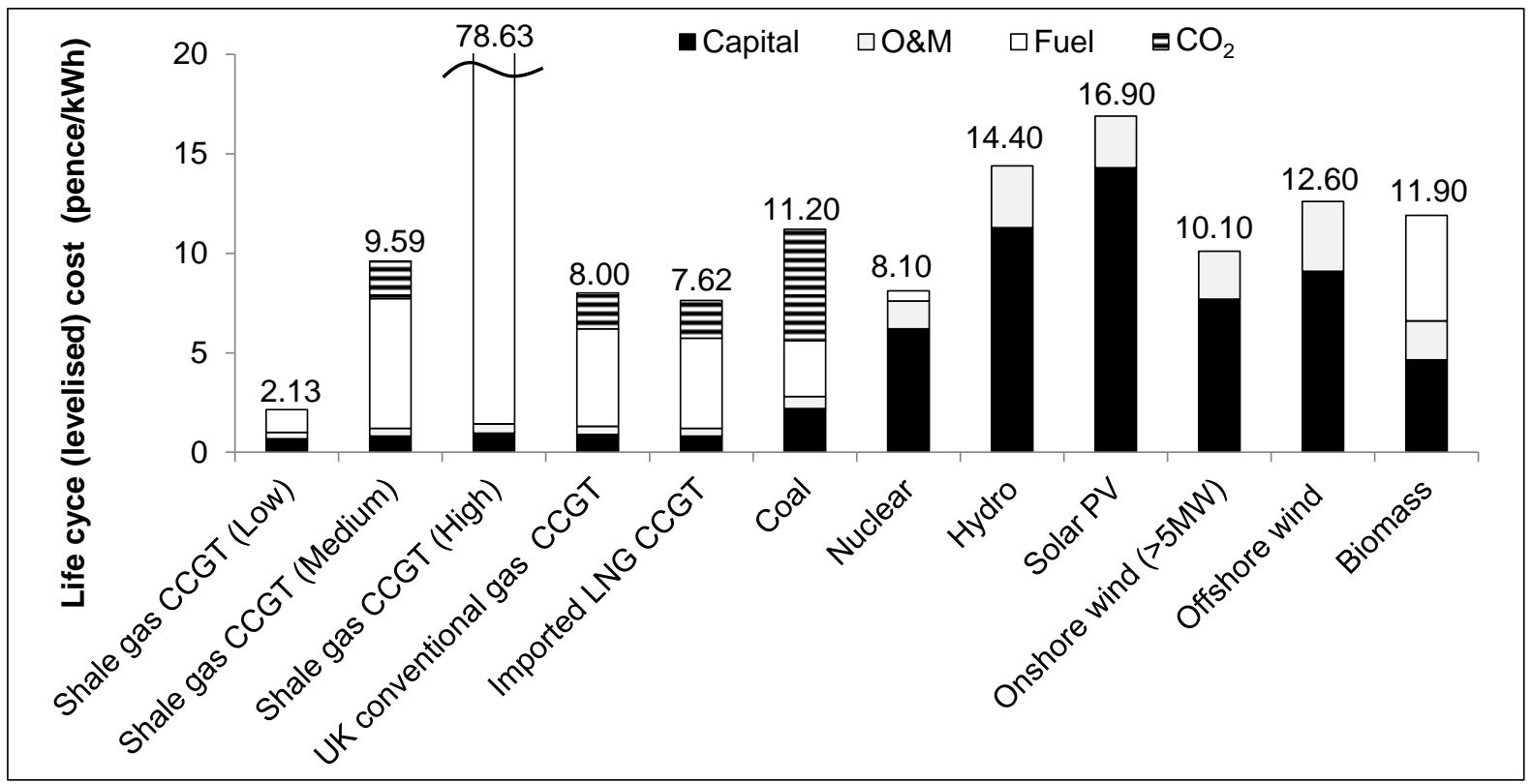

Figure 5: Comparison of the present life cycle (levelised) costs of shale gas electricity with other electricity sources in the UK.

[Shale gas CCGT (Low): high estimated ultimate recovery (EUR) and low costs of combined cycle gas turbine (CCGT) power plant; Shale gas CCGT (Medium): average EUR and medium power plant costs; Shale gas CCGT (High): low EUR and high power plant costs. Discount rate: 10\%; for details see Table 11. Costs for other technologies estimated based on data from DECC (2012a) and IRENA (2012). O\&M: operating and maintenance costs. LNG: liquefied natural gas.]

\subsection{Scenario analysis}

\subsubsection{Cost of gas in 2030}

The costs of gas to the power plant in 2030 have been estimated using the same method as for the current costs (see Section 2.2.2), based on the prices of different gas sources and their contribution to the gas mix given in Table 7. The results in Figure 6 suggest that for the high penetration of shale gas $(28.4 \%$ in the gas mix), the gas costs would be around $7 \%$ higher than for the low penetration (4.5\%). This is due to shale gas being more expensive than gas imports and UK North Sea gas (see Table 7).

When no shale gas in the mix is considered, the cost of gas is similar to that for low shale gas penetration (2.66 vs 2.62 pence/kWh, respectively). In the case of high penetration, the average cost would be $8 \%$ higher than without it. However, as can be seen in Figure 6 , there is a great variation in the values, so the cost could be up to six times higher in the worst case and up to $30 \%$ lower in the best case. To validate the results to some extent, the estimated cost without shale gas is compared to that reported in the literature (Figure 6), showing good agreement. The relative difference of $7 \%$ is due to differing gas mixes and prices, the latter of which were modelled in the literature (BEIS, 2016a) based on the current and projected conditions of the European gas market while the current study used UK market data.

The effect of the level of penetration of shale gas on the cost of generating gas electricity is discussed in the next section. 


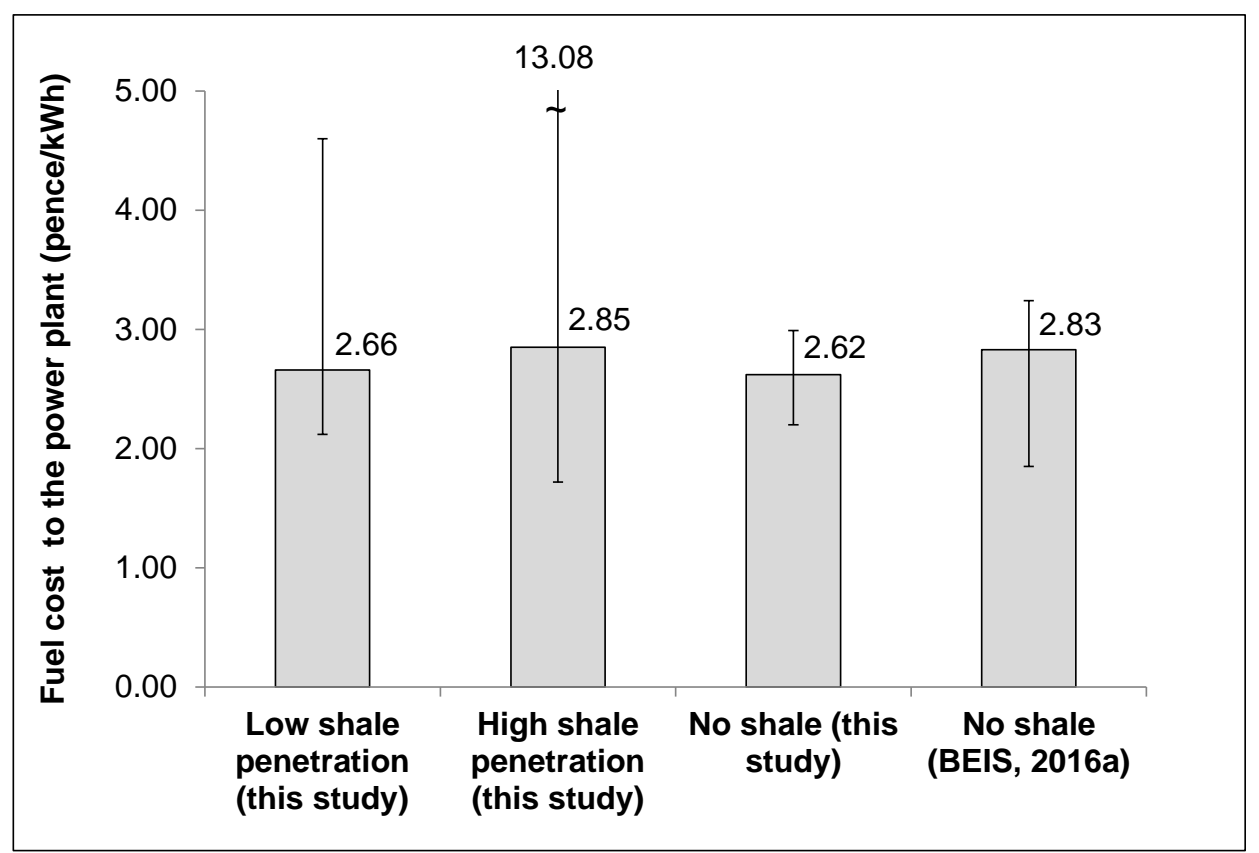

Figure 6: Costs of fuel to power plants $\left(C F_{E}\right)$ in 2030 for low and high shale gas penetration in comparison with no shale gas in the mix.

[The break-even price of shale gas at 10\% discount rate (Table 9) has been used along with the prices of the other gas options (Table 7) to calculate the cost of the gas mix in 2030 based on their contribution to the mix. This value has then been used to estimate the gas costs to the power plant by adding the additional costs listed in Table 6. The values on top of the chart bars represent costs for the average EUR and the error bars correspond to low and high EUR.]

\subsection{2. $\quad$ Costs of electricity in 2030}

\subsubsection{Costs of electricity from gas}

The estimated costs of gas to the power plant discussed in the previous section have been used to calculate the life cycle (levelised) cost of electricity generation from the assumed 2030 gas mix using eqn. (10). As can be seen in Figure 7, there is only a small difference $(4 \%)$ in the average cost of electricity with the low or high shale gas penetration (8.10 vs 8.46 pence/kWh, respectively). Following the trends in the gas prices from the previous section, the high-penetration mix has higher LCC. These costs are also similar to the average costs without shale gas in the mix (8.03 pence/kWh). Thus, the impact of shale gas on the costs of future gas electricity would be insignificant. The only exception to this is for the high-shale case, where the cost is more than double the highest cost of electricity without shale gas.

The average estimated cost with no shale gas is $5 \%-10 \%$ lower than that reported in the literature; see Figure 6 . It can also be noticed from the figure that the literature estimates of average electricity costs without shale slightly exceed or are similar to the values estimated here for both low and high penetration of shale gas. This is due to at least two factors: different assumptions in the studies and the small effect of shale gas on the costs of electricity generation (1.7\%-12\%; shale gas contributes $4.5 \%-28.4 \%$ to the gas mix and fuel costs make up $62 \%-77 \%$ of the $\left.L C C_{E}\right)$.

Compared to the present average costs of electricity from gas of 5.80 pence/kWh (DECC, 2012a), the 2030 costs estimated in this study are around 30\% higher. A similar increase in costs is also reported by DECC (2012a) and BEIS (2016a). This is largely due to the need to build an additional 26 GW of CCGT plants by 2030 (DECC, 2012b; BEIS, 2016b). 


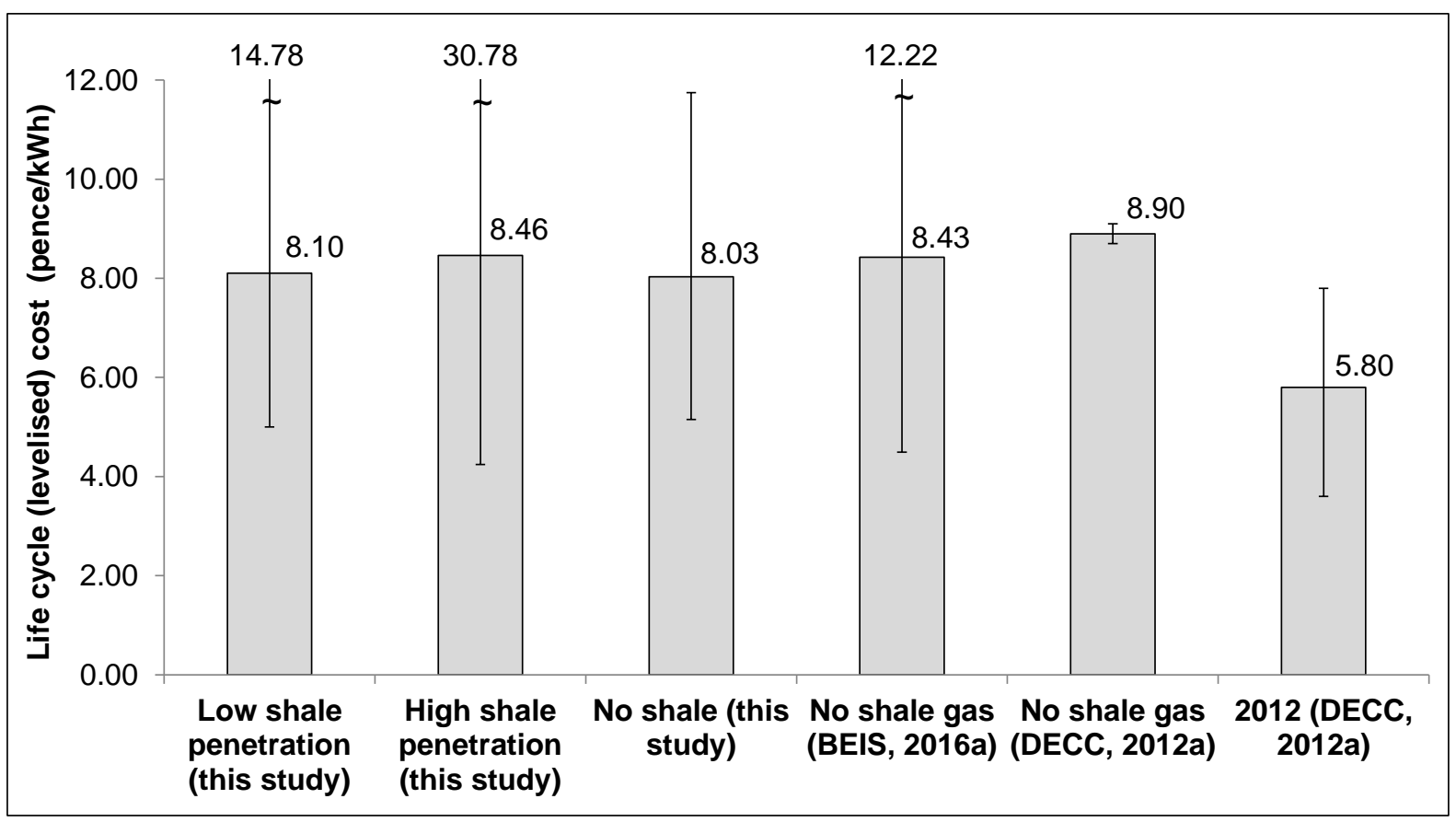

Figure 7: Estimated life cycle (levelised) costs of electricity $\left(L C C_{E}\right)$ in 2030 for low and high penetration of shale gas in comparison with no shale gas in the mix.

[This study: The values on top of the chart bars represent costs for the average EUR and medium power plant costs. The error bars correspond to low and high EUR of shale gas as well as low and high power plant costs. Literature: The values on top of the bars are average costs and the error bars correspond to low and high values.]

\subsubsection{Costs of electricity mix}

Similar to the previous findings, the level of shale gas penetration into the electricity mix has little effect on future costs of electricity. As shown in Figure 8 (and detailed in Table S4 in the $\mathrm{SI})$, the LCC in the central case are estimated at 9.40-9.48 pence/kWh for the low and high penetrations of shale gas in 2030, respectively. Thus, the difference in costs between the two scenarios is almost indistinguishable, with the higher-shale electricity being slightly more expensive. These costs are also quite close to those without shale gas in the mix, estimated at 9.38 pence/kWh, thus suggesting that shale gas will not influence costs of electricity mix under the conditions considered in this study. As also shown in Figure 8, the estimates of electricity costs without shale gas are slightly lower than those calculated in this study from the literature data (9.47-9.71 pence/kWh) for comparison purposes. As before, the reason for this difference is different assumptions for various costs.

To determine the potential effect of shale gas on consumer electricity bills, Figure 8 also shows the estimated wholesale prices of electricity in 2030 . It can be seen that the annual price of wholesale electricity increases by around 10\%, from $£ 281$ in 2013 up to $£ 310$ in 2030. However, this increase is largely due to the predicted increase of low-carbon technologies and CCS in the electricity mix, despite the expectation that the costs of most renewables and nuclear power will decrease by 2030 (see Figure S1 in the SI). 


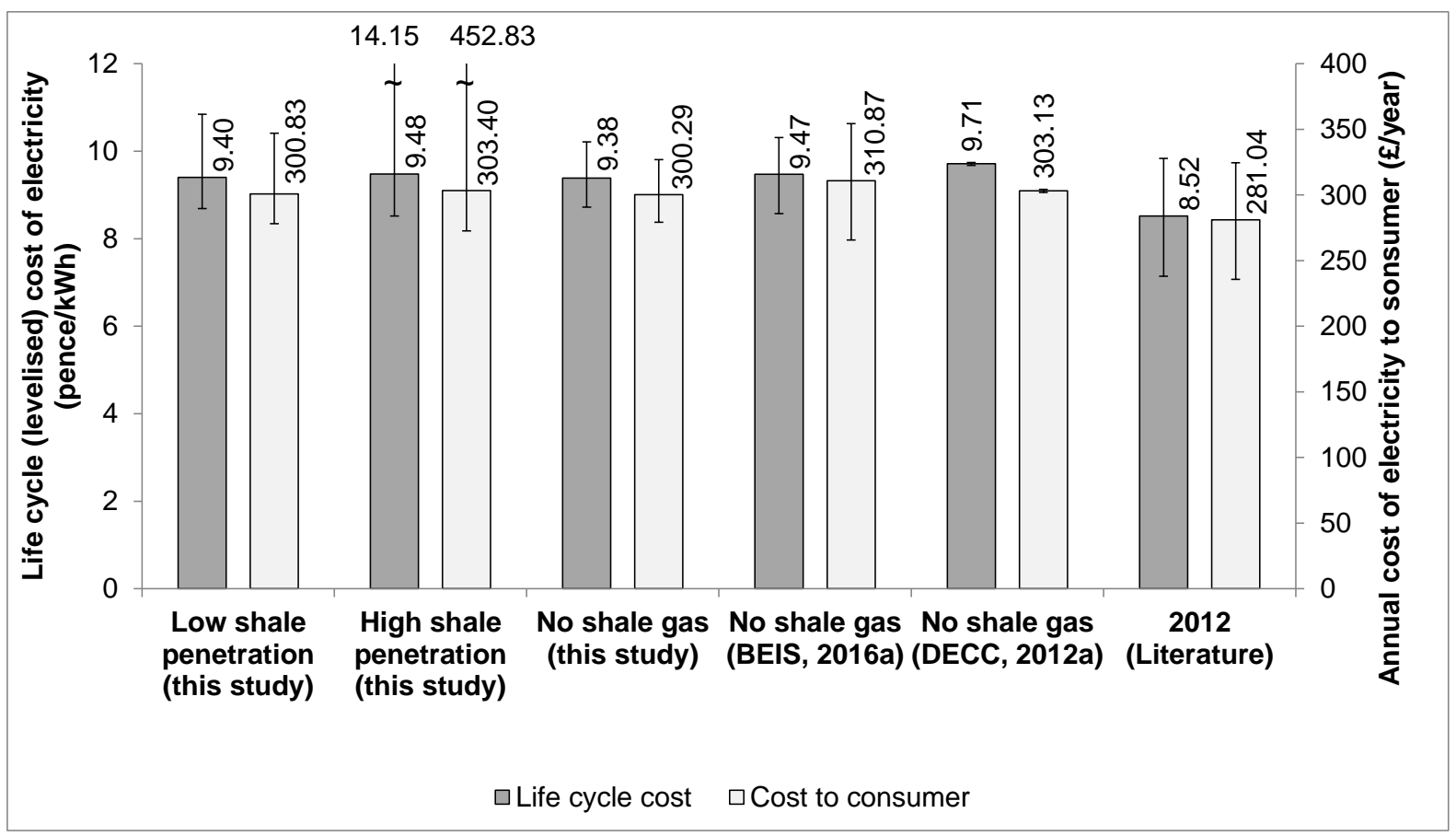

Figure 8: Estimated life cycle (levelised) and annual electricity costs to consumer in 2030 for low and high penetration of shale gas in comparison with no shale gas in the mix

[The values on top of the chart bars represent the average costs in the central case. This study: Error bars correspond to low and high costs of gas electricity (Figure 7) and worst and best electricity scenarios (see Table 8 for specifications of the central, best and worst scenarios). No shale gas (BEIS, 2016a; DECC, 2012a): Error bars correspond to low and high values. These have been estimated in this work using literature gas fuel costs in Figure 6 and cost of gas electricity in 2030 reported by DECC (2012a). 2012 (Literature): Data sourced from DECC (2012a); Ofgem (2013); DECC (2013c); British Gas (2016); EDF Energy (2016); eon (2016); npower (2016); ScottishPower (2017); SSE (2017). Cost to consumer estimated from LCC assuming annual consumption of $3200 \mathrm{kWh}$ per household.]

\section{Conclusions}

This study has assessed the economic viability of UK shale gas and the impacts it could have on the domestic gas and electricity markets, both at present and in the medium-term future, up to 2030. The life cycle costs are estimated in the range of $0.13-15.76$ pence/ $\mathrm{kWh}$, with an average value of 1.29 pence/kWh. The break-even price at which shale gas can be sold ranges from 0.26-31.79 pence/kWh, averaging at 2.63 pence/kWh (9.47 pence/MJ). This is more expensive than imported LNG (1.20 pence/kWh) and UK conventional gas (1.76-1.98 pence/kWh). It is also around three times more expensive than US shale gas.

The costs of producing shale gas are primarily dominated by capital (hydraulic fracturing) and labour costs. The majority of the hydraulic fracturing costs are for equipment because this will most likely have to be imported from the US. The labour costs are high, in spite of low job generation, because the average salary in the oil and gas industry is high and jobs in gas extraction are over a long period. The labour costs also expected to increase because of the need to import skilled shale-gas workforce currently not available in the UK.

Shale gas costs are sensitive to three parameters: estimated ultimate recovery (EUR) and related volume of gas produced, discount rate and the price at which the gas is sold. The results suggest that shale gas is competitive with domestic conventional gas at low discount rates $(<3 \%)$. At discount rates below $10 \%$ and high overall gas production volume, the price of shale gas is much lower than the price of conventional North Sea gas, but is higher than US shale gas and market prices in other parts of the world. Despite this, under the circumstances at which shale gas could be profitable, £35-67 M in revenue could be 
generated per well ( $£ 140-266$ bn for 4000 wells), as well as $£ 11-20 \mathrm{M}$ in tax revenue ( $£ 42-80$ bn for 4000 wells). However, this would be a small boost to the UK economy, contributing $0.017 \%-0.033 \%$ to the GDP. This is much lower than the contribution of US shale gas to the US GDP $(0.2 \%)$, indicating that the economic effect of shale gas on the UK economy would be significantly lower than in the US.

The LCC of shale gas electricity range from 2.02-132.25 pence/kWh for the discount rates of $5 \%-30 \%$, depending on the costs of the power plant and the EUR. For the medium power plant costs and average EUR, the LCC are 9.59 pence/kWh, which is $17 \%$ higher than electricity from UK conventional gas and $20 \%$ greater than power from imported LNG. Nevertheless, it is still more competitive than most other electricity options, except for nuclear which has similar costs to electricity from domestic conventional gas. In the worst case, however, the LCC of shale gas electricity are ten times higher than of conventional gas and almost five times greater than the costs of solar PV which is the most expensive alternative among the other options considered. However, the cost benefits of shale gas over other electricity options diminish as fuel costs increase.

The findings in this work also suggest that shale gas will have little effect on future (2030) gas and electricity costs, with the high penetration of shale gas leading to slightly higher prices than the low penetration. The impact on future electricity bills would also be negligible, partly as a result of the expected increase of low-carbon technologies and CCS in the mix.

However, if shale gas is to be developed in the UK, it is important that appropriate measures be put in place to improve its cost competiveness with other energy options and maximise the benefits from its exploitation. Given that the majority of the costs are due to the hydraulic fracturing equipment and labour, the industry and government should invest in development of fracturing technology and skilled workforce. This would not only reduce costs in the longer term but would also reduce the dependence on imported equipment and labour. It is also important to consider the costs of environmental damage from shale gas exploitation (the consideration of which was beyond the scope of this paper). Thus, government should establish an environmental legacy fund to be used for compensating environmental damage caused by shale gas development. While this will increase the total costs of shale gas development in the short term, the overall benefits from protecting the environment will be greater over the long term. Shale gas companies should also set up a fund overseen by the government to cover the costs of well decommissioning and land remediation so that the burden is not borne by the tax payer. The fund should cover the full cost of plugging and other decommissioning activities, as well as well integrity monitoring in later years. Furthermore, to prolong the economic benefits of shale gas, government could establish a sovereignty fund similar to that in Norway and Qatar, investing the tax revenue collected into assets and projects not related to shale gas.

Although the results of this study suggest that shale gas may not be economically viable as a fuel for electricity generation, the economic implications of its use for heat generation or a feedstock in the chemicals industry are as yet unknown and should be explored further. Future work should also consider the above-mentioned and other policy measures in detail to quantify potential effects on the costs of and benefits from shale gas development.

\section{Nomenclature}

$b$

$C C_{E, k}$

$\mathrm{CCO}_{2 k}$

$C C_{S G, n}$

$C F_{E, k}$

$C L_{S G, n}$

$\operatorname{COM}_{E, k}$
Arps decline exponent (-)

capital cost of the power plant in year $k$ (£/year)

cost to the power plant of emitting $\mathrm{CO}_{2}$ in year $k$ ( $($ /year)

capital cost of producing shale gas in year $n$ ( $($ year)

cost of fuel to the power plant in year $k$ ( $£ /$ year)

labour costs of shale gas production in year $n$ ( $£ /$ year)

operating and maintenance costs of electricity generation in year $k$ ( $£ /$ year) 


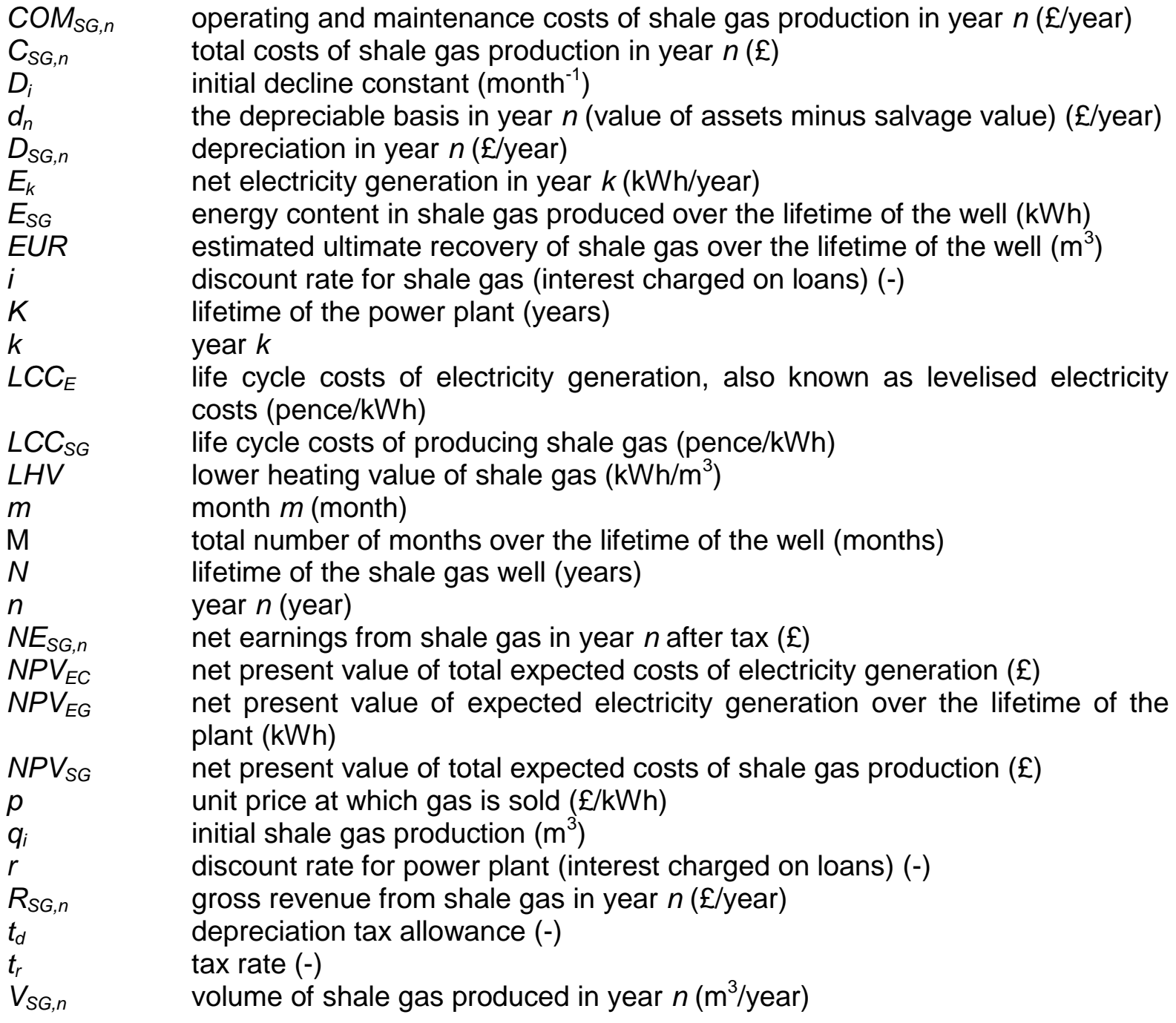

\section{Acknowledgements}

This work was funded by the UK Engineering and Physical Sciences Research Council (grant no. EP/K011820/1) and the University of Manchester's Alumni Donor Society. This funding is gratefully acknowledged.

\section{References}

ACC. 2011. Shale gas and new petrochemicals investment: Benefits for the economy, jobs, and US manufacturing, Washington DC, US.

AMEC. 2013. Strategic environmental assessment for further onshore oil and gas licensing. Department of Energy and Climate Change (DECC). London, UK. Retrieved from: https://www.gov.uk/government/consultations/environmental-report-for-furtheronshore-oil-and-gas-licensing.

Amion. 2014. Potential economic impacts of shale gas in the Ocean Gateway. IGas Energy plc and Peel Environment Ltd. Liverpool, UK. Retrieved from: http://www.igasplc.com/media/10851/ocean-gateway-shale-gas-impact-study.pdf.

Andrews, I. J. 2013. The Carboniferous Bowland Shale gas study: geology and resource estimation. British Geological Society (BGS). London, UK. Retrieved from: https://www.gov.uk/government/uploads/system/uploads/attachment data/file/22687 4/BGS DECC BowlandShaleGasReport MAIN REPORT.pdf.

BEIS. 2016a. BEIS 2016 Fossil Fuel Price Assumptions. Department for Business, Energy and Industrial Strategy (BEIS). London, UK. Retrieved from: 
https://www.gov.uk/government/uploads/system/uploads/attachment data/file/57654 2/BEIS 2016 Fossil Fuel Price Assumptions.pdf.

BEIS. 2016b. Digest of United Kingdom Energy Statistics 2016. Department for Business, energy and Industrial Strategy (BEIS). London, UK. Retrieved from: https://www.gov.uk/government/uploads/system/uploads/attachment data/file/57771 2/DUKES 2016 FINAL.pdf.

BEIS. 2016c. Electricity generation costs. Department for Business, Energy and Industrial Strategy (BEIS). London, UK. Retrieved from: https://www.gov.uk/government/uploads/system/uploads/attachment data/file/56656 7/BEIS Electricity Generation Cost Report.pdf.

BEIS. 2016d. UK Energy in Brief 2016. Department for Business, Energy and Industrial Strategy (BEIS). London, UK. Retrieved from: https://www.gov.uk/government/statistics/uk-energy-in-brief-2016.

Berman, A. E. and Pittinger, L. F. 2011. US shale gas: less abundance, higher cost. [Online], 5 August. Available: http://www.theoildrum.com/node/8212 [Accessed: February 2017].

Bide, T., Brown, T. J., Hobbs, S. F. and Idoine, N. 2014. United Kingdom minerals year 2013. British Geological Survey (BGS). London. Retrieved from: https://www.bgs.ac.uk/downloads/start.cfm?id=2930.

BIS. 2015. Growth Dashboard. June 2015. gov.uk. London, UK. Retrieved from: https://www.gov.uk/government/uploads/system/uploads/attachment data/file/39674 0/bis-15-4-growth-dashboard.pdf.

BNEF. 2013. The economic impact on UK energy policy of shale gas and oil. April, 2014. Bloomberg New Energy Finance (BNEF). London, UK. Retrieved from: http://about.bnef.com/white-papers/the-economic-impact-on-uk-energy-policy-ofshale-gas/.

Bolton, R. and Foxon, T.J. 2014. Environmental Innovation and Societal Transitions, 14, $165-181$.

Bonakdarpour, M., Flanagan, B., Holling, C. and Larson, J. W. 2011. The economic and employment contributions of shale gas in the United States. IHS Global. Washington DC. Retrieved from: http://energyindepth.org/wp-content/uploads/2011/12/ShaleGas-Economic-Impact-Dec-2011 EMB1.pdf.

Bonetti, L. 2014. Shale gas and Germany's energiewende: A cost-benefit analysis for the power generation sector. MSc Thesis, Norwegian School of Economics.

BP. 2014. BP statistical review of world energy June 2014. British Petroleum (BP). London, UK. Retrieved from: http://www.bp.com/content/dam/bpcountry/de de/PDFs/brochures/BP-statistical-review-of-world-energy-2014-fullreport.pdf.

BP. 2016a. BP Energy Outlook: 2016 edition. British Petroleum (BP). London, UK. Retrieved from: https:/www.bp.com/content/dam/bp/pdf/energy-economics/energyoutlook-2016/bp-energy-outlook-2016.pdf.

BP. 2016b. BP Statistical Review of World Energy June 2016. British Petroleum (BP). London, UK. Retrieved from: https://www.bp.com/content/dam/bp/pdf/energyeconomics/statistical-review-2016/bp-statistical-review-of-world-energy-2016-fullreport.pdf.

British 2016. Our fuel mix [Online]. Available: http://www.britishgas.co.uk/business/about-us/fuel-mix [Accessed February 2017].

Chen, Z., Osadetz, K. G. and Chen, X. 2015. Economic appraisal of shale gas resources, an example from the Horn River shale gas play, Canada. Petroleum Science, 12, 712725.

Chou, E. 2013. Shale gas in China - development and challenges. Cambridge, MA, US.

Conti, J. J., Holtberg, P. D., Diefenderder, J. R., Napolitano, S. A., Schaal, M., Turnure, J. T. and Westfall, L. D. 2015. Annual energy outlook 2015 with projections to 2040. Energy Information Administration (EIA). Washington DC. Retrieved from: http://www.eia.gov/forecasts/aeo/pdf/0383\%282015\%29.pdf. 
Cook, P., Beck, V., Brereton, D., Clark, R., Fisher, B., Kentish, S., Toomey, J. and Williams, J. 2013. Engineering energy: unconventional gas production. Melbourne, Australia.

Cooper, J., Stamford, L. and Azapagic, A. 2014. Environmental impacts of shale gas in the UK: Current situation and future scenarios. Energy Technology, 2, 1012-1026.

Cooper, J., Stamford, L. and Azapagic, A. 2016. Shale gas: A review of the economic, environmental and social sustainability. Energy Technology, 4, 772 -792.

Cooper, J., L. Stamford and A. Azapagic (2018). Social sustainability assessment of shale gas in the UK. Sustainable Production and Consumption. 14 1-20.

Cronin, K. 2013. Community engagement charter oil and gas from unconventional reservoirs. UK Onshore Oil and Gas (UKOOG). London, UK. Retrieved from: https://www.gov.uk/government/uploads/system/uploads/attachment data/file/25636 0/Publication UKOOG communityengagementcharterversion6.pdf.

Crooks, E. 2016. Oil and gas: Debt fears flare up. Financial Times, 21 March 2016, Available from: https://www.ft.com/content/d48b1922-eadd-11e5-bb79-2303682345c8.

Cuadrilla Resources. 2017a. Fracturing fluid [Online] Preston, UK. Available: http://www.cuadrillaresources.com/what-we-do/hydraulic-fracturing/fracturing-fluid/ [Accessed 2017 February].

Cuadrilla Resources. 2017b. Our Lancashire sites [Online] Preston, UK. Available: http://www.cuadrillaresources.com/our-sites/lancashire-sites/ [Accessed February 2017].

DECC. 2012a. Electricity generation costs. Department of Energy and Climate Change. London, UK. Retrieved from: https://www.gov.uk/government/uploads/system/uploads/attachment data/file/65713/ 6883-electricity-generation-costs.pdf.

DECC. 2012b. Gas Generation Strategy. Department of Energy and Climate Change (DECC). London, UK. Retrieved from: https://www.gov.uk/government/uploads/system/uploads/attachment data/file/65654/ 7165-gas-generation-strategy.pdf.

DECC. 2013a. Electricity generation costs. Department of Energy and Climate Change (DECC). London, UK. Retrieved from: https://www.gov.uk/government/publications/electricity-generation-costs-december2013.

DECC. 2013b. Onshore oil and gas exploration in the UK: regulation and best practice. Department of Energy and Climate Change (DECC). London, UK. Retrieved from: https://www.gov.uk/government/uploads/system/uploads/attachment data/file/50306 7/Onshore UK oil and gas exploration England Dec15.pdf.

DECC. 2013c. Updated energy and emissions projections 2013. Department of Energy and Climate Change (DECC). London, UK. Retrieved from: https://www.gov.uk/government/uploads/system/uploads/attachment data/file/23993 7/uep 2013.pdf.

Deloitte. 2013. Oil and gas taxation in the UK: Deloitte taxation and investment guides. Deloitte. London, UK. Retrieved from: https://www2.deloitte.com/content/dam/Deloitte/global/Documents/Energy-and-

Resources/dttl-er-UK-oilandgas-guide.pdf.

Duman, R. J. 2012. Economic viability of shale gas production in the Marcellus Shale; indicated by production rates, costs and current gas prices. Masters thesis, Michigan Technological University.

EDF Energy. 2016. Our fuel mix EDF Energy [Online]. Available: http://www.edfenergy.com/fuel-mix [Accessed February 2017].

EIA. 2011. Review of emerging resources: U.S. shale gas and shale oil Plays. US Energy Information Administration (EIA). Washington DC. Retrieved from: https://www.eia.gov/analysis/studies/usshalegas/pdf/usshaleplays.pdf.

eon. 2016. Fuel mix [Online]: eon. Available: https://www.eonenergy.com/About-eon/FuelMix [Accessed February 2017]. 
FERC. 2017. 2017. World LNG Estimated Landed Prices: Dec-16 [Online], Federal Energy Regulatory Commission (FERC), January 2017. Available from: https://www.ferc.gov/market-oversight/mkt-gas/overview/ngas-ovr-Ing-wld-pr-est.pdf.

FT. 2016. Commodities [Online] London, UK: Financial Times (FT). Available: http://markets.ft.com/research/markets/Commodities [Accessed February 2017].

Fullenbaum, R. F., Larson, J. W. and Dorsey, J. 2011. The economic and employment contributions of shale gas in the United States. IHS Global Insight (USA). Washington DC. Retrieved from: http://anga.us/media/content/F7D1750E-9C1EE786-674372E5D5E98A40/files/shale-gas-economic-impact-dec-2011.pdf.

Gosden, E. 2017. Cuadrilla starts drilling at Lancashire fracking site. The Times, 18 August 2017, Available from: https://www.thetimes.co.uk/article/cuadrilla-starts-drilling-atlancashire-fracking-site-qn85dgtkf.

Gosden, E. and Shiel, T. 2015. Fracking: UK shale gas exploration sites mapped. The Telegraph, 28 January, 2015, Available from: http://www.telegraph.co.uk.

HM Revenues and Customs. 2011. Mineral Royalties Relief: Repeal. HM Revenues and Customs. London, UK. Retrieved from: https://www.gov.uk/government/uploads/system/uploads/attachment data/file/19214 5/ots mineral royalties.pdf.

HM Revenues and Customs. 2016a. Climate change levy rates [Online] London, UK: HM Revenues and Customs. Available: https://www.gov.uk/government/publications/rates-and-allowances-climate-changelevy/climate-change-levy-rates [Accessed February 2017].

HM Revenues and Customs. 2016b. VAT rates [Online] London, UK: HM Revenues and Customs. Available: https://www.gov.uk/vat-rates [Accessed February 2017].

HM Treasury. 2013. Autumn statement 2013, The Crown, London, UK.

HM Treasury. 2014. Autumn statement 2014, The Crown, London, UK.

House of Lords. 2014. The economic impact on UK energy policy of shale gas and oil. May, 2014. House of Lords: Economic Affairs Committee. London, UK. Retrieved from: http://www.publications.parliament.uk/pa/ld201314/ldselect/ldeconaf/172/172.pdf.

ICIS. 2013. Heren European Spot Gas Market ICIS (Independent Chemical Information Service). London. Retrieved from: http://www.icis.com/energy/gas/europe/europeanspot-gas-markets/.

ICIS. 2014. Heren LNG Markets Daily. ICIS (Independent Chemical Information Service). Retrieved from: http://www.icis.com/energy/liquefied-natural-gas/lng-daily-andweekly-reports/.

IEA. 2015. Key world energy statistics. International Energy Agency (IEA). Paris, FR. Retrieved from: http://www.iea.org/publications/freepublications/publication/KeyWorld Statistics 201 5.pdf.

IRENA. 2012. Hydropwer. International Renewable Energy Agency (IRENA). Abu dhabi, UAE. Retrieved from: http://www.irena.org/documentdownloads/publications/re technologies cost analysis -hydropower.pdf.

Kuuskraa, V. A., Stephens, S. H. and Moodhre, K. D. 2013. Technically recoverable shale oil and shale gas resources: An assessment of 137 shale formations in 41 countries outside the United States. U.S. Energy Information Administration (EIA). Washington DC. Retrieved from: https://www.eia.gov/analysis/studies/worldshalegas/.

Lewis, C., Speirs, J. and MacSweeney, R. 2014. Getting ready for UK shale gas: Supply chain and skills requirements and opportunities. United Kingdon Onshore Oil and Gas and Ernst and Young. London, UK. Retrieved from: http://www.ey.com/Publication/vwLUAssets/Getting ready for UK shale gas/\$FILE/ EY-Getting-ready-for-UK-shale-gas-April-2014.pdf.

Mersich, A. 2013. Potential economic impacts of developing Quebec's shale gas. Calgary, Canada. 
Moniz, E. J., Jacoby, H. d., Meggs, A. J. M., Armstrong, R. C., cohn, D. R., Connors, S. R., Deutch, J. M., Ejaz, Q. J., Hezir, J. S., Kaufman, G. M., Kenderdine, M. a., O'Sullivan, F., Paltsev, S., Parsons, J. E., Perez-Arriaga, I., Reilly, J. M., Seto, C., Webster, M. D., Yang, Y., McRae, G. S. and Ruppel, C. 2011. The future of natural gas: an interdisciplinary MIT study. Massachusetts Institute of Technology Energy Initiative (MITEI). Cambridge, MA, USA. Retrieved from: https://mitei.mit.edu/system/files/NaturalGas_Report.pdf.

Moore, V., Bereford, A., Gove, B., Underhill, R., Parnham, S., Crow, H., Cunningham, R., Huyton, H., Sutton, J., Melling, T., Billings, P. and Salter, M. 2014. Hydraulic fracturing for shale gas in the UK: Examining the evidence for potential environmental impacts. The Royal Society for the Protection of Birds (RSPB). London, UK. Retrieved from: https://www.rspb.org.uk/Images/shale gas report evidence tcm9365779.pdf.

Mott MacDonald. 2010. UK electricity generation costs update. Department of Energy and Climate Change (DECC). Brighton, UK. Retrieved from: https://www.gov.uk/government/uploads/system/uploads/attachment data/file/65716/ 71-uk-electricity-generation-costs-update-.pdf.

National Grid. 2016. The statement of gas transmission transportation charges. National Grid. London, UK. Retrieved from: http://www2.nationalgrid.com/UK/Industryinformation/System-charges/Gas-transmission/Charging-Statements/.

npower. 2016. Where our electricity comes from: Fuel mix [Online] Houghton le Spring, UK. Available: http://www.npower.com/home/about-npower/our-responsibility/how-wesource-our-fuels/ [Accessed February 2017].

Office for Budget Responsibility. 2016. Economic and fiscal outlook. Office for Budget Responsibility. London, UK. Retrieved from: http://budgetresponsibility.org.uk/efo/economic-fiscal-outlook-march-2016/.

Ofgem. 2013. Updated household energy bills explained Ofgem. London, UK. Retrieved from: https://www.ofgem.gov.uk/ofgempublications/64006/householdenergybillsexplainedudjuly2013web.pdf.

Oil \& Gas UK. 2010. Economic Report 2010. Oil \& Gas UK. Aberdeen, UK. Retrieved from: http://oilandgasuk.co.uk/wp-content/uploads/2015/05/EC021.pdf.

ONS. 2010. Annual Business Inquiry, 2008 Revised Results [Online]: Office for National Statistics (ONS). Available: http://webarchive.nationalarchives.gov.uk/20160105160709/http://www.ons.gov.uk/on s/rel/abs/annual-business-inquiry/index.html [Accessed February 2017].

ONS. 2013. Annual survey of hours and earning UK, 2013. December 2013. Office for National Statistics (ONS). London, UK. Retrieved from: http://www.ons.gov.uk/ons/rel/ashe/annual-survey-of-hours-and-earnings/2013provisional-results/stb-ashe-statistical-bulletin-2013.html.

Parsons Brinckerhoff. 2013. Electricity generation cost model- 2013 update of nonrenewable technoligies. Department of Energy and Climate Change (DECC). Manchester, UK. Retrieved from: https://www.gov.uk/government/uploads/system/uploads/attachment data/file/22363 4/2013 Update of Non-Renewable Technologies FINAL.pdf.

ScottishPower. 2017. Bill breakdown. ScottishPower. Glasgow, UK. Retrieved from: http://www.scottishpower.co.uk/customer-services/bills-payments/billbreakdown/.

Smil, V. 2015. Natural gas: fuel for the 21st century, First, Chinchester, UK: Wiley.

SONRIS. 2013. Well Information. Strategic Online Natural Resources Information System (SONRIS): Baton Rouge, LA, USA (March 2014) Retrieved from: http://sonlite.dnr.state.la.us/sundown/cart prod/cart con wellinfo1.

SSE. 2017. Energy legal and regulatory information [Online] Perth, UK. Available: https://sse.co.uk/help/energy/energy-regulations\#item1 [Accessed February 2017].

Statista. 2017. Gross domestic product at current market prices of the United Kingdom (UK) from 2000 to 2015 (in million GBP) [Online] New York, NY, USA. Available: 
https://www.statista.com/statistics/281744/gdp-of-the-united-kingdom-uk-since-2000/ [Accessed January 2017].

Statistics Norway. 2017. External trade in goods [Online] Oslo, NO: Statistics Norway. Available:

https://www.ssb.no/statistikkbanken/SelectVarVal/Define.asp?subjectcode=01\&Prod uctld $=01 \&$ MainTable $=$ UhArOljeGass\&SubTable $=1 \&$ PLanguage $=1 \&$ nvl $=$ True \&Qid $=0 \&$ gruppe1=Hele\&gruppe2=Europa2\&gruppe3=Hele\&aggreg2=NO\&VS1=VareGruppeO ljeGass\&VS2=LandkoderEnkeltland\&VS3=\&mt=0\&KortNavnWeb=muh\&CMSSubject Area $=\&$ StatVariant=\&checked=true [Accessed February 2017].

Symmons, D., Rushing, J. A. and Blasingame., T. A. 2010. Hybrid Rate-Decline Models for the Analysis of Production Performance in Unconventional Reservoirs (Conference). SPE Annual Technical Conference and Exhibition. 19-22 September 2010 Florence, IT.

Taylor, C. and Lewis, D. 2013. Getting shale gas working. Institute of Directors (loD). London, UK. Retrieved from: www.iod.com/ /media/.../loD Getting shale gas working MAIN REPORT.pdf.

The World Bank. 2017. Data [Online] Washington DC. Available: http://data.worldbank.org/ [Accessed February 2017].

Third Energy. 2016. Assets and operations: Onshore [Online] East Knapton , UK: Third Energy. Available: https://www.third-energy.com/assets-operations [Accessed February 2017].

Tian, L., Z. Wang, A. Krupnick and X. Liu 2014. Energy Policy, 75, 109-116.

Towler, G. and Sinnot, R. 2008. Chemical engineering design: Principles, practice and economics of plant and process design, London, UK: Elsevier.

Trading Economics. 2017. United Kingdom prime lending rates [Online]: Trading Economics. Available: $\quad$ http://www.tradingeconomics.com/united-kingdom/bank-lending-rate [Accessed February 2017].

UKOOG, 2013, United Kingdom Onshore Oil and Gas launches shale community engagement charter [Press release] London, UK: United Kingdom Onshore Oil and Gas (UKOOG). Available: http://www.ukoog.org.uk/about-ukoog/press-releases/58united-kingdom-onshore-oil-and-gas-launches-shale-community-engagementcharter.

Villalobos, D. 2013. Review of typical domestic consumption values. Office of Gas and Electricity Markets (Ofgem). London, UK. Retrieved from: https://www.ofgem.gov.uk/sites/default/files/docs/2013/09/tdcv-reviewconsultation 0.pdf.

Weijermars, R. 2013. Economic appraisal of shale gas plays in Continental Europe. Applied Energy, 106, 100-115.

Weijermars, R., Sorek, N., Sen, D. and Ayers, W. B. 2017. Eagle Ford Shale play economics: U.S. versus Mexico. Journal of Natural Gas Science and Engineering, 38, 345-372.

Weng, Y. and Hefley, W. E. 2016. The global impact of unconventional shale gas development: economics, policy and interdependence, First ed, Zug, Switzerland: Springer International.

Werner, A. K., Vink, S., Watt, K. and Jagals, P. 2015. Environmental health impacts of unconventional natural gas development: A review of the current strength of evidence. Science of The Total Environment, 505, $1127-1141$.

Wexelstein, L. 2014. 2014. The North Sea: How does the UK compare? [Online], January 2015. Presentation. Available from: https://www.woodmac.com/.

Williams, J., Field, L. and Lee, E. 2011. The impact of unconventional gas in Europe: $A$ report to Ofgem. Poyry (for Ofgem). Warrington. Retrieved from: https://www.ofgem.gov.uk/ofgempublications/38113/033publicreportunconventionalgasofgemlogov41.pdf.

Yunna, W. and Yisheng, Y. 2014. Renewable Sustainable Energy Revies, 40, 798 - 805. 


\section{Supplementary information}

1. Capital costs of a shale gas well

Table S1: Capital cost of a shale gas well (Amion, 2014; Cronin, 2013; Lewis et al., 2014; Taylor and Lewis, 2013).

\begin{tabular}{|c|c|c|c|c|}
\hline \multicolumn{2}{|c|}{ Activity } & Cost per well (M£) & & \\
\hline \multirow{3}{*}{\multicolumn{2}{|c|}{$\begin{array}{l}\text { Seismic testing } \\
\text { Pre-licensing and enabling } \\
\text { Exploration and appraisal }\end{array}$}} & 0.02 & & \\
\hline & & 0.01 & & \\
\hline & & 1.50 & & \\
\hline \multicolumn{2}{|c|}{ Hydraulic fracturing } & 5.14 & & \\
\hline \multicolumn{2}{|c|}{ Equipment } & 4.27 & & \\
\hline \multicolumn{2}{|c|}{ Proppant } & 0.51 & & \\
\hline \multicolumn{2}{|c|}{ Chemicals } & 0.19 & & \\
\hline \multirow{2}{*}{\multicolumn{2}{|c|}{ Mobilisation/demobilisation }} & 0.11 & & \\
\hline \multirow{2}{*}{\multicolumn{2}{|c|}{$\begin{array}{l}\text { Miscellaneous } \\
\text { Drilling and completion }\end{array}$}} & 0.06 & & \\
\hline & & 2.07 & & \\
\hline \multicolumn{2}{|c|}{ Steel casing } & 0.58 & & \\
\hline \multicolumn{2}{|c|}{ Rig hire } & 0.54 & & \\
\hline \multicolumn{2}{|c|}{ Ancillary equipment and services } & 0.30 & & \\
\hline \multicolumn{2}{|c|}{ Cementing } & 0.21 & & \\
\hline \multicolumn{2}{|c|}{ Directional drilling } & 0.19 & & \\
\hline \multicolumn{2}{|c|}{ Drilling fluid } & 0.14 & & \\
\hline \multicolumn{2}{|c|}{ Drill rig fuel } & 0.12 & & \\
\hline \multicolumn{2}{|c|}{ Storage and transportation } & 0.32 & & \\
\hline \multicolumn{2}{|c|}{ Waste transportation } & 0.19 & & \\
\hline \multicolumn{2}{|c|}{ Water storage } & 0.03 & & \\
\hline \multicolumn{2}{|c|}{ Water transportation } & 0.10 & & \\
\hline \multicolumn{2}{|c|}{ Waste disposal } & 0.69 & & \\
\hline \multicolumn{2}{|c|}{ Water management } & 0.36 & & \\
\hline \multicolumn{2}{|c|}{ Drilling waste } & 0.33 & & \\
\hline \multicolumn{2}{|c|}{ Decommissioning } & 0.28 & & \\
\hline \multicolumn{2}{|c|}{ Community charter (initial lump-sum payment) ${ }^{a}$} & $2.5 \times 10^{-3}$ & & \\
\hline & 0.13 & & \\
\hline & & 0.01 & & \\
\hline \multicolumn{2}{|c|}{$\begin{array}{l}\text { Pad preparation, construction and security } \\
\text { Gathering and gas processing }\end{array}$} & $0.04-0.05$ & & \\
\hline Other & & $0.07-0.08$ & & \\
\hline Total & & 10.16 & & \\
\hline $\begin{array}{l}\text { a The annual } \\
\text { a variable cos }\end{array}$ & ments are not included as they & $\mathrm{d}$ on the annual produ & tion of shale ge & nd are therefore \\
\hline Table S2: & $\begin{array}{l}\text { Sand and chemicals re } \\
\text { al., 2014; Cooper et al., }\end{array}$ & $\begin{array}{l}\text { d for hydraulic } f \\
\text {; Cuadrilla, 2013 }\end{array}$ & $\begin{array}{l}\text { acturing in } \\
\text { Lewis et al. }\end{array}$ & $\begin{array}{l}\text { UK (Bide et } \\
14) \text {. }\end{array}$ \\
\hline & Sand & & Chemicals & \\
\hline Number of $\mathrm{w}$ & Quantity (t) & $\operatorname{Cost}(M £)$ & Quantity $(\mathrm{kg})$ & $\operatorname{Cost}(M £)$ \\
\hline One horizont & 2250 & 0.507 & 88 & 0.187 \\
\hline Four horizont & 9000 & 2 & 350 & 0.748 \\
\hline Well pad with & 90,000 & 20 & 3500 & 7.48 \\
\hline $\begin{array}{l}\text { Peak product } \\
\text { fractured ann }\end{array}$ & $\begin{array}{l}\text { ( } 400 \text { wells } \\
\text { ly) }\end{array}$ & 200 & 35,000 & 74.8 \\
\hline
\end{tabular}


Table S3: $\quad$ Estimated break-even prices of shale gas for different discount rates and expected ultimate recovery (EUR) values.

\begin{tabular}{lrrrrr}
\hline Price (pence/kWh) & \multicolumn{2}{c}{ Discount rate } & & & \\
& $5 \%$ & $10 \%$ & $15 \%$ & $20 \%$ & $30 \%$ \\
\hline Low EUR & 25.67 & 31.79 & 37.78 & 43.69 & 55.47 \\
Average EUR & 2.13 & 2.63 & 3.13 & 3.62 & 4.60 \\
High EUR & 0.21 & 0.26 & 0.31 & 0.35 & 0.45 \\
\hline
\end{tabular}

Table S4: Life cycle (levelised) costs for 2030 electricity for different electricity and shale gas scenarios.

\begin{tabular}{|c|c|c|c|}
\hline \multirow[b]{2}{*}{ Shale gas scenario } & \multicolumn{3}{|c|}{$\begin{array}{c}\text { Costs for different electricity scenarios } \\
\text { (pence/kWh) }\end{array}$} \\
\hline & Best & Central & Worst \\
\hline \multicolumn{4}{|l|}{ Low shale penetration } \\
\hline Low EUR & 10.92 & 10.90 & 10.48 \\
\hline Average EUR & 9.40 & 9.40 & 9.46 \\
\hline High EUR & 8.69 & 8.71 & 8.82 \\
\hline \multicolumn{4}{|l|}{ High shale penetration } \\
\hline Low EUR & 14.56 & 14.48 & 14.15 \\
\hline Average EUR & 9.48 & 9.48 & 9.54 \\
\hline High EUR & 8.52 & 8.54 & 8.67 \\
\hline
\end{tabular}

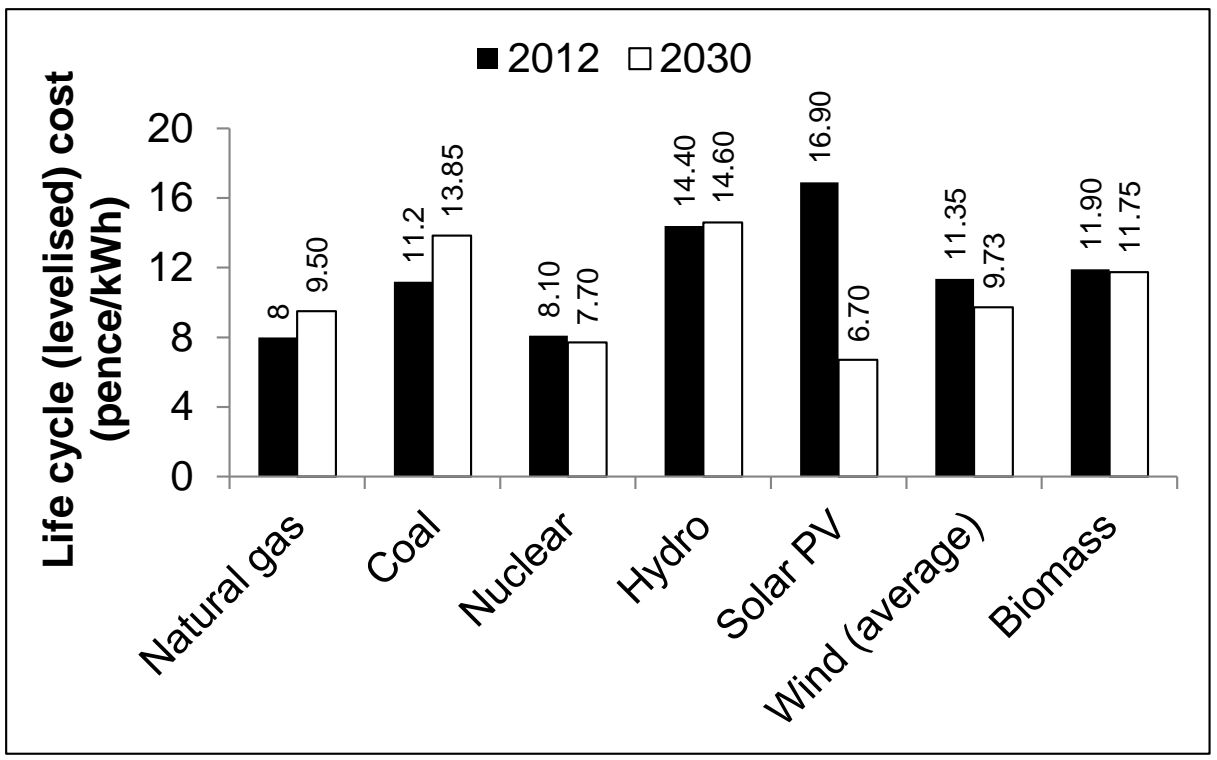

Figure S1: Comparison of 2012 and 2030 life cycle (levelised) costs of different electricity sources in the UK

[2012 costs: DECC (2012; 2013). 2030 costs: DECC (2013). "Wind average": average costs of offshore and onshore installations.]

\section{References}

Amion. 2014. Potenital economic impacts of shale gas in the Ocean Gateway. IGas Energy plc and Peel Environment Ltd. Liverpool, UK. Retrieved from:

http://www.igasplc.com/media/10851/ocean-gateway-shale-gas-impact-study.pdf.

Bide, T., Brown, T. J., Hobbs, S. F. and Idoine, N. 2014. United Kingdom minerals year 2013. British Geological Survey. London. Retrieved from.

Cooper, J., Stamford, L. and Azapagic, A. 2014. Environmental impacts of shale gas in the UK: Current situation and future scenarios. Energy Technology, 2, 1012-1026.

Cronin, K. 2013. Community engagement charter oil and gas from unconventional reservoirs. United Kingdon Onshore Oil and Gas (UKOOG). London, UK. Retrieved from: http://www.ukoog.org.uk/community/charter. 
Applied Energy, https://doi.org/10.1016/j.apenergy.2018.02.051

Cuadrilla. 2013. Fracturing Fluid [Online]. Available:

http://www.cuadrillaresources.com/what-we-do/hydraulic-fracturing/fracturing-fluid/ [Accessed 2014].

DECC. 2012. Electricity generation costs. Department of Energy and Climate Change. London, UK. Retrieved from:

https://www.gov.uk/government/uploads/system/uploads/attachment data/file/65713/ 6883-electricity-generation-costs.pdf.

DECC. 2013. Electricity generation costs. Department of Energy and Climate Change (DECC). London, UK. Retrieved from:

https://www.gov.uk/government/publications/electricity-generation-costs-december2013.

Lewis, C., Speirs, J. and MacSweeney, R. 2014. Getting ready for UK shale gas: Supply chain and skills requirements and opportunities. United Kingdon Onshore Oil and Gas and Ernst and Young. London, UK. Retrieved from:

http://www.ey.com/Publication/vwLUAssets/Getting ready for UK shale gas/\$FILE/ EY-Getting-ready-for-UK-shale-gas-April-2014.pdf.

Taylor, C. and Lewis, D. 2013. Getting shale gas working. Institute of Directors (loD). London, UK. Retrieved from:

www.iod.com/ /media/.../loD Getting shale gas working MAIN REPORT.pdf. 